\title{
The Thesean Ritual Landscape. APPROPRIATION, IDENTITY AND Athenian Collective Memories
}

El paisaje Ritual de Teseo.

APROPIACIÓN, IDENTIDAD Y MEMORIA COLECTIVA ATENIENSE

Ben S. Cassell

King's College London ben.cassell@kcl.ac.uk

\section{Abstract}

A key aspect of Theseus's exponential growth in popularity between the $6^{\text {th }}-4^{\text {th }}$ cent. BCE, was an increased association with various festivals and their ritualized acts. Most prominently, it was the episode of the Cretan adventure that informed these rites. In their claimed, and emphasized, Thesean

\section{RESUMEN}

Un aspecto clave del crecimiento exponencial de la popularidad de Teseo entre los siglos VI y IV a.C. fue su creciente asociación con varios festivales y actos ritualizados. Fue especialmente el episodio de la aventura cretense el que dio forma a estos ritos. En sus reivindicadas y enfatizadas 
aetiologies, these festivals are revealed as vital mechanisms by which the cultural collective memory of the hero was generated. Moving beyond simply approaching ritual as an expressive mnemonic object, this paper considers the contingent and re-constructive methods by which this collective memory was produced. Moreover, by examining the embodied experience of recalling Theseus, we are provided much firmer ground in commenting on their formative force on various Athenian identities. etiologías teseicas, estos festivales se revelan como mecanismos esenciales mediante los cuales se generaba la memoria cultural colectiva del héroe. Más allá de abordar simplemente el ritual como un objeto de expresión mnemónica, este artículo analiza los métodos contingentes y reconstructivos mediante los que se produce la memoria colectiva. Además, al examinar la experiencia corporeizada del recuerdo de Teseo, podemos valorar sobre un terreno mucho más firme su potencia creadora de diversas identidades atenienses.

\section{Palabras Clave}

Collective Memory; Embodied Cognition; Identity; Mnemotopography; Theseus.

\section{Keywords}

Cognición corporal; identidad; memoria colectiva; mnemotopografía; Teseo. 


\section{INTRODUCTION}

From the $6^{\text {th }}$ cent. BCE the figure of Theseus underwent an overt expansion in his narratological schema, visual depiction and presence within the socio-cultural/religious landscape of Attica. ${ }^{1}$ A vital aspect of this latter phenomenon manifested in the appropriative emphasis and evocation of Thesean origins within various ritual contexts. The aim of this paper is to examine how those rites associated with the Cretan expedition, through claiming a Thesean aetiology and aspects of their physical execution, provided arenas in which collective memories essential to differing socialized identities were generated. In order to appreciate their formative force these rites, and the role of Theseus within them, will not be considered as monolithically inherited and experienced media, but rather as situationally contingent manifestations; structured by and structuring exterior socio-cultural realities of the $6^{\text {th }}-5^{\text {th }}$ cent. BCE. ${ }^{2}$ Fundamentally, I aim to better illustrate how these rituals acted to cultivate a collective cultural memory of Theseus within their participants, employing the criteria established by Maurice Halbwachs and since refined by Jan Assmann. ${ }^{3}$ This form of social memory relates to the origins of the group as based around distinct personages, places and episodes, requiring collective evocation and spatial orientation, such as via mnemotopography. ${ }^{4}$ As will be seen, the commemorative recollection of Theseus did not act abstractly within these rituals, but in conjunction with specific spaces and episodes.

1. Brommer, 1982, pp. 35-50; Calame, 1996, pp. 143-162; Neils, 1995, p. 17; Walker, 1995, pp. 20 and 35; Van den Hoff, 2010, pp. 177-179.

2. Rüpke, 2018a, pp. 11-15.

3. Assmann, 2012, pp. 21-45.

4. Connerton, 1989, p. 44; Halbwachs, 1992, p. 200. 
I also aim to sensitize this examination by considering the manner in which the embodied experience and mimesis central to many of these rites could contribute to aged, gendered and civic identities. ${ }^{5}$ This requires a consideration of the cognitive impact of a given rite, to which the religious modes theory of Harvey Whitehouse provides a helpful basis. Here "doctrinal" rituals, regular and low in sensory/emotive arousal, are argued as producing semantic memory and wider group identification, while irregular and dysphoric "imagistic" rites aid in smaller group fusion via shared episodic memories. ${ }^{6}$ However I shall not rigidly apply Whitehouse's definitions, but rather follow recent discussions on their applicability to ancient Greek religion by highlighting aspects that align either with the two modes, or indeed "cognitively optimal" and intuitive religious action. ${ }^{7}$ In applying the theoretical frameworks of cultural memory studies and cognitive approaches to religion in tandem, we are provided with a fuller understanding and a new point of departure in analysing the mechanics and formative force of these rituals. Indeed rather than simply approach them as "institutional mnemonic objects", we are afforded a clearer illustration of the socialized, and interactive, generation of collective memory within their participating groups. ${ }^{8}$

\section{The Cretan Adventure, Elaboration of Thesean Myth, and Plutarch's Life of Theseus}

As noted above, the central narratological focus of the rites discussed below was that of Theseus' journey to and return from Crete, which alongside his abduction of Helen and battle with the Lapiths against the Centaurs, belonged to the earliest development of Thesean myth. ${ }^{9}$ The earliest textual mention of this episode is found in Homer who mentions Ariadne being killed by Artemis on Dia, ${ }^{10}$ yet debates on this passage being a later $6^{\text {th }}$ cent. interpolation still continue. ${ }^{11}$ Nevertheless Hesiod illustrates its being current during the late $8^{\text {th }}$ cent. at least, noting an alternative fate

\footnotetext{
5. Connerton, 1989, pp. 72-73.

6. Whitehouse, 2002, pp. 296-303; Whitehouse and Lanman, 2014, p. 674.

7. Larson, 2016, p. 193.

8. Beim, 2010, pp. 1-23.

9. Shapiro, 1991, p. 123; Neils, 1994, p. 942; Walker, 1995, pp. 15-20.

10. Od. XI 321-325.

11. Walker, 1995, p. 16.
} 
for Ariadne who married Dionysus. ${ }^{12}$ Sappho certainly composed on the expedition during the $7^{\text {th }}$-early $6^{\text {th }}$ cent., as did Simonides during the latter $6^{\text {th }}$ cent. ${ }^{13}$

Thus by the $6^{\text {th }}$ cent. BCE the Cretan adventure is firmly illustrated as an established episode within both epic and lyric compositions. It is from this period that we may discern the hero's emerging popularity in Athens itself. ${ }^{14}$ The famous Françoise Vase (ca. $570 \mathrm{BCE}$ ) provides our first Attic depiction of the episode, illustrating the arrival of Theseus at Crete with the sacrificial youths and maidens and being welcomed by Ariadne. ${ }^{15}$ From the middle of the century, newer episodes involving the taming of the Marathon Bull and the rape of Antiope first appear in ceramic and sculptural art. The so-called Saronic Cycle, the civilizing journey of the youthful Theseus from Troezen, also emerged after ca. $515 .{ }^{16}$ It is also in the last quarter of the $6^{\text {th }}$ cent. that an epic, epics/comedies, the Theseis are generally agreed to have been composed, while not directly mentioned until the $4^{\text {th }}$ cent. by Aristotle. ${ }^{17}$ The exact focus of this work, as well as its very existence, are still issues of debate and reciting them here does not serve our current purpose.$^{18}$ It is also unhelpful to attribute the promotion and elaboration of Theseus within Athens to any specific political personality, instead noting as far as possible contextual manifestations throughout the $6^{\text {th }}-4^{\text {th }}$ cent. BCE. ${ }^{19}$ This includes the intersecting notions of Theseus' synoecism of Attica. Both Valdés Guía and Luce indicate this as emerging within the Solonian period, and his initiation of proto-democracy which naturally flourished after the reforms of Kleisthenes in 508 BCE..$^{20}$ Contextually significant aspects of the appropriative emphasis of Theseus will be discussed below, noting here that collective memory always proceeds in a re-constructive relationship to the present; a process vividly evident in Athens across the $6^{\text {th }}-4^{\text {th }}$ cent. BCE. ${ }^{21}$

Admittedly our primary source for commenting on these rituals is comparatively late, coming in Plutarch's Life of Theseus, which was likely composed towards the end of the authors' life in $120 \mathrm{CE} .^{22}$ As a work, the Theseus displays various levels

\footnotetext{
12. Theog. $947-949$.

13. Sapph., fr. 206; Simon., fr. 54 = Plut., Thes. 17, 6.

14. Bernabé Pajares, 1992, pp. 97-118; Walker, 1995, p. 46.

15. Hedreen, 2011, pp. 491-493.

16. Neils, 1987, pp. 32-37; Shapiro, 1991, pp. 134-136.

17. Poet. 1451a 19-21. Cf. Cingano, 2017, pp. 9-16.

18. Neils, 1987, p. 144; Bernabé Pajares, 1992.

19. Kron, 1976, p. 224; Calame, 1996, pp. 416-417; Walker, 1995, p. 47.

20. Kearns, 1989, p. 119; Luce, 1998, pp. 19-30; Goušchin, 1999; Valdés Guía, 2009, pp. 11-30.

21. Shapiro, 2012, p. 160; Cusumano, 2013, pp. 17-19.

22. Frost, 1984, p. 70.
} 
of both typological and referential intertextuality, and his descriptions of Thesean ritual must be considered in relation to this. Most prominently the Life of Theseus naturally interacts with its moralized pairing with Romulus by Plutarch, wherein the foundational quality of both these figures is emphasized..$^{23}$ A primary aspect to this dual characterization is the initiation of religious festivals, that while coming in a fairly compartmentalized description in the Life of Romulus (21-22) are more sporadic in relation to Theseus. This certainly operates within the balancing parallelism which Plutarch constructs in this pairing, yet in contrast to Romulus, and indeed the other Lives, the Theseus is indicated as being a product of specific research. Beginning the Theseus, Plutarch falsely indicates that he will purify mythic elements out of his

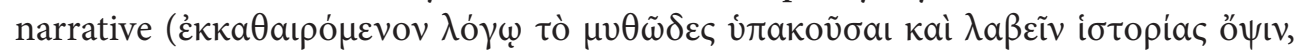
1.3), nevertheless admitting them under scrutiny. In this way Plutarch frames his biography of Theseus outside of the historical inquiry of Polybius, instead adopting a form of historiographic archaeology that is applying scrutiny to "mythic" aspects. ${ }^{24}$ This intertextual nod towards the historical methods of Polybius in fact establishes Plutarch's divergent biographical focus, as engaged in the historiographic archaiologia of Diodorus and Dionysus. ${ }^{25}$

It is here that the validity of Plutarch's Life of Theseus as a source for commentary on $5^{\text {th }}-4^{\text {th }}$ cent. BCE ritual becomes apparent, as it included the direct citation of works and authors from those periods. Indeed the Theseus shows very little interaction with the rest of Plutarch's corpus, instead adopting an expressly intertextual quality by frequently referencing the works of the Atthidographers and his own eye witnesses. ${ }^{26}$ As a collection of authors, the so-called Atthidographers were focused on etymology, cult and various aetiological origins, employing both oral tradition and research into topography and physical remains; representing a social knowledge and communal memory of the past. ${ }^{27}$ Not only does Plutarch employ these sources when describing the rituals under discussion here, but indeed adopts an antiquarian timbre himself, resting as we shall see below on oral accounts and his own observation. Thus as a source, while chronologically divorced from the periods under discussion here, the Life of Theseus provides a valuable framework for analysing the contingent and operational aspects of Thesean ritual in the Classical era. With these aspects of the

23. Larmour, 1988, p. 362.

24. Cooper, 2007, p. 212.

25. Cooper, 2007, p. 222.

26. Cooper, 2007, p. 228; Brenk, 2017, p. 121.

27. Harding, 2008, pp. 2-12.

ARYS, 18, 2020 [213-255] ISSN 1575-166X 
intertextual quality of Plutarch's Theseus in mind we will now examine the formative, mnemonic, potential of these "Thesean" rites.

\section{The OSCHOPHORIA. RECALLED LANDSCAPES AND EMBODIED REMEMBERING}

The festival of the Oschophoria was celebrated on the $7^{\text {th }}$ of Pyanopsion (October/ November), and is widely recognized as relating to autumn sowing and the vintage. ${ }^{28}$ Its structure of action, as described by Plutarch, consisted of a procession from an undisclosed shrine of Dionysus in Athens to the temple of Athena Skiras at the port of Phaleron where feasting and games took place. ${ }^{29}$ That this framework existed in the Classical era is attested in the well-known $4^{\text {th }}$ cent. BCE stele first discussed by Ferguson, ${ }^{30}$ in which the genos Salaminioi are revealed as selecting the important roles of oschophori and deipnophoroi from their own number. ${ }^{31}$ However the appropriative emphasis on the Thesean origins of this festival are indicated as beginning within the Archaic period.

Several elements of the Oschophoria, which will be detailed below, have led to the festival being identified as overtly Dionysian during the Archaic period up until the start of the $6^{\text {th }}$ cent. BCE. ${ }^{32}$ Indeed the festival even as it manifested in the later Archaic and Classical periods, has been suggested as containing distinct aspects of Bronze Age vegetation cults. ${ }^{33}$ Valdés Guía has produced a detailed argument in underling how the rites of the Oschophoria had a long history by the date of the Salaminian decree and that it, like other festivals, underwent changes especially at the time of the conquest of Salamis in the early $6^{\text {th }}$ cent. ${ }^{34}$ The details of this "conquest" and the role of the genos Salaminioi in the cult of Athena Skiras are still issues of debate. For some the Salaminioi along with the cult were imported during the late $6^{\text {th }}$ cent. ${ }^{35}$ or emigrated to Attica during the Dark Ages,${ }^{36}$ or indeed had no rela-

\footnotetext{
28. Parker, 2005, p. 477; Larson, 2016, p. 214.

29. Pitz, 2011, p. 153.

30. SEG 21.

31. Ferguson, 1938, p. 6.

32. Valdés Guía, 2002, pp. 187-203; Parker, 2005, pp. 213-217; for an alternative view see Scullion, 2007, pp. 196-201.

33. Simon, 1996, p. 21.

34. Valdés Guía, 2002, pp. 195-200.

35. Walker, 1995, pp. 50 and 99.

36. Osborne, 1994, pp. 154-160.
} 
tionship with the island at all. ${ }^{37} \mathrm{~A}$ more convincing position is that taken by Lambert and Valdés Guía, who see the genos Salaminioi as being based within Athens/ Attica during the Archaic period with close ties to the island. ${ }^{38}$ They posit that the Solonian conflict with Megara and invasion of the island at the start of the century initiated the adaptation of the Oschophoria. Valdés Guía argues that this caused the "urbanization" of the cult at the centre of the Oschophoria, with the Salamis-Athens centric Athena Skiras replacing Aphrodite/Ariadne. ${ }^{39}$ It is also likely that up until the late $6^{\text {th }}$ cent., and possible establishment of a cleruchy by Kleisthenes, the island changed hands more than once. However by the end of the century the island was certainly being settled by Athenians, ${ }^{40}$ while several black-figure vases depicting Athena in conversation with Dionysus from this period may depict the Oschophoria. ${ }^{41}$ Thus while identified with the earliest Dionysian/Aphrodisian form of the Oschophoria, Theseus' overt prominence in this festival throughout the Classical era is indicated as beginning in the $6^{\text {th }}$ cent. ${ }^{42}$ Indeed if the adjustment of the festival to include Athena Skiras was aimed at incorporating Salamis more fully into Attica, Thesean connections to the island would naturally be promoted, on which more below. Moreover while Dionysian elements are certainly present in Plutarch's description of the Oschophoria, these are given specific Thesean aetiologies, while in the $4^{\text {th }}$ cent. Salaminian stele Dionysus does not appear in conjunction with the festival, or indeed at all. ${ }^{43}$ This certainly indicates, if not a complete elision of the god, an appropriative emphasis on existing Thesean elements in line with the introduction of Athena Skiras during the $6^{\text {th }}$ cent. BCE.

In describing the Oschophoria Plutarch openly states his use of "the history" of

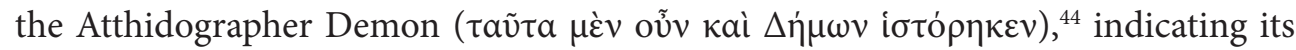
overt evocation of Theseus as being present in $5^{\text {th }}$ cent. BCE. Plutarch also openly

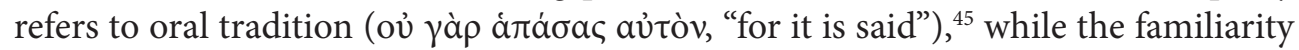
of the descriptions suggest his having witnessed it himself. ${ }^{46}$ The commemoration of Thesean aetiologies within the Oschophoria, present its composite rites as focusing

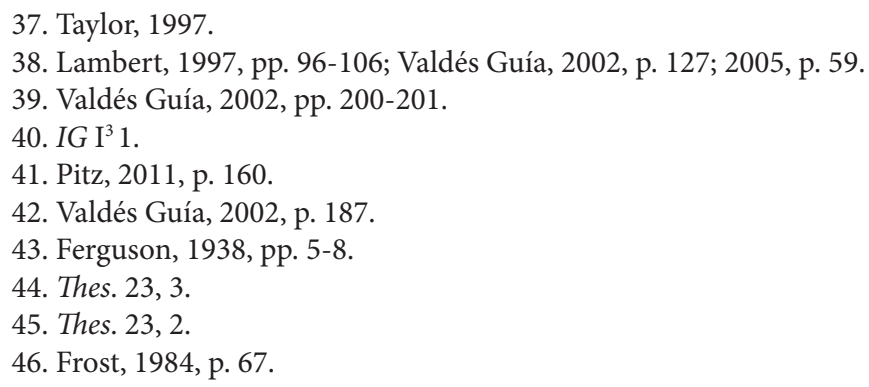

37. Taylor, 1997.

38. Lambert, 1997, pp. 96-106; Valdés Guía, 2002, p. 127; 2005, p. 59.

39. Valdés Guía, 2002, pp. 200-201.

40. $I G \mathrm{I}^{3} 1$.

41. Pitz, 2011, p. 160.

42. Valdés Guía, 2002, p. 187.

43. Ferguson, 1938, pp. 5-8.

44. Thes. 23,3 .

45. Thes. 23, 2.

46. Frost, 1984, p. 67. 
on the re-enactive mimesis of his departure, return from Crete and foundation of the festival, within a holistic temporal framework. The procession itself would have acted to reiterate and spatially evoke the collective memory of these events through its physical mimesis. Mnemotopography is essential in cultivating cultural memory; allowing shared pasts to be anchored and evidenced most especially via collective pilgrimage ${ }^{47}$ In effect, the Oschophoric procession enabled the recollection of the Cretan adventure through the act of re-performing Theseus' original movement through the landscape towards the port. Moreover, the constituent elements of the ritual demonstrate the facilitation of an embodied remembering that would have aided in the construction of aged, gendered, genos and civic identities.

A notable feature of the procession was its being led by two epheboi, the oschophori as recorded on the $4^{\text {th }}$ cent. BCE stele, who adopted female attire and

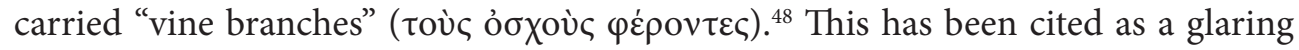
example of the Dionysian flavour of the Oschophoria, on which more briefly. Yet in Plutarch it is firmly correlated into the orbit of the Cretan expedition; replication of the subterfuge of Theseus who disguised two youths as maidens and upon re-

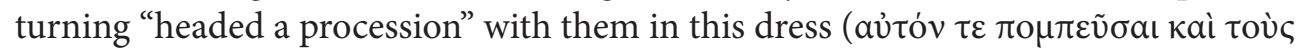

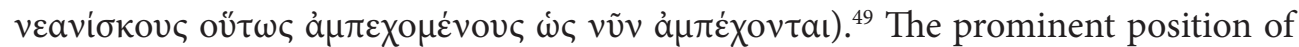
vine branches during the processions, as well as its departure from a shrine of Dionysus, again suggest an older cultic focus of the Oschophoria. Plutarch however provides Thesean origins for this feature noting, along with Apollodorus, ${ }^{50}$ it honouring the union of Ariadne and Dionysus. He also notes that it may simply be due to the fact that the Thesean expedition returned to Phaleron "at the time of the vintage". In any regard, the presence of vine branches is ascribed specifically to Theseus' return from Crete by Plutarch's $5^{\text {th }}$ cent. source, Demon:

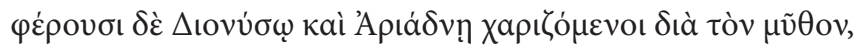

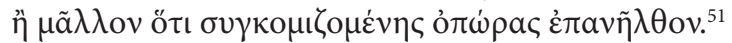

In claiming a distinct Thesean origin for this specific facet of the ritual, the Oschophoria provided its general participants with a material reminder of the origin of the festival. For collective cultural memory to formulate within groups such material signalling is

47. Assmann, 2012, p. 44.

48. Thes. 23,3 .

49. Thes. 23,3 .

50. Epit. 1, 9.

51. FGrHist 327, 6 = Plut., Thes. 23, 3. 
essential, whether via reproduction or relics ascribed to specific episodes from the past..$^{52}$ In this instance, we may suggest that the vine branches would have provided a visual testament to the foundation of the festival by Theseus for general attendees.

We gain a clearer understanding of how this collectively mnemonic communication could aid in the formulation of identity, if we consider the epheboi who carried the branches. As well as operationally evoking the journey to and return from Crete to the procession's participants, the dress of the youths entailed the active adoption of a character from this narrative. ${ }^{53}$ Plutarch relates how Theseus taught the original youths to "imitate maidens in their speech, dress and gait" ( $\delta 1 \delta \dot{\xi} \xi \alpha \nu \tau \alpha \varphi \omega v \eta े \nu$

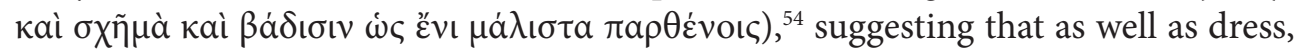
the oschophoroi may have adopted a stylized form of movement also. This re-performance of Theseus' initial ruse and successful parade back to Athens, would clearly evoke the recollection of the Thesean origins of the festival. Such perceptions of direct continuation from the past into the present via ritualized forms is essential to collective memory. ${ }^{55}$ Yet as individuals, the elision of the self through the wearing of female clothing and adoption of proto-typical characters, would have provided a distinct avenue for the formation of socialized identities. ${ }^{56}$ Essentially this form of embodied narration would formulate the semantic memory of the Oschophoria's foundation in those participating youths; incorporating an episode from the wider collective past into their experience of the festival. ${ }^{57}$ Moreover the episodic recollection of this experience can be suggested as enabling the "fusion" of the oschophoroi into a maturing age group. Indeed while Whitehouse suggests this manner of group cohesion as only coming about via dysphoric trauma, this has been criticized, with ecstatic, sensorially limited, or rites concerned with maturation having been noted as also enabling strong episodic memories. In the case of the Oschophoria, female dress would have both signalled and aided in forming the maturing identity of those participating young men. ${ }^{58}$

The description of female dress being adopted by the oschophoroi is singular to Plutarch's quoting of Demon:

52. Alcock, 2002, p. 28; Jones, 2007, p. 12; Hewer and Roberts, 2012, p. 176.

53. Böhr, 2007, p. 70.

54. Thes. 23, 2.

55. Assmann, 2012, pp. 41-44.

56. Brown, 2013, pp. 58-60.

57. Connerton, 1989, p. 88.

58. Schjødt et al., 2013, pp. 39-43; G. Downey in Whitehouse and Lanman, 2014, p. 684. 


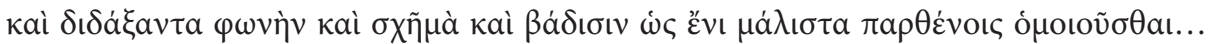

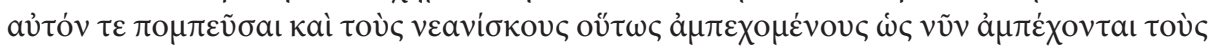

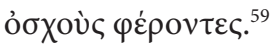

Other Atthidographers such as Philochorus neglect to record it. ${ }^{60}$ However transvestism played a vital role in the transitional points of various Greek heroes including Odysseus and Heracles. ${ }^{61}$ In Plutarch's description of Theseus training the youths, we may also detect a more contemporaneous interaction with Statius' Achilleid of the $1^{\text {st }}$ cent. CE. Here the transvestism of a youthful Achilles as achieved by his mother Thetis, is also brought about initially by the wearing of female dress and then by teaching him "how to walk and move and how to speak with modesty" (et picturato cohibens vestigia limbo incessum motumque docet fandique pudorem). ${ }^{62}$ This may indicate Plutarch as operating within current literary templates, and we may tentatively suggest an intertextual reference here, but only insofar as it aligns with an already established aspect of Thesean myth.

Indeed the value of Plutarch's description of the Oschophoria is its presentation of a framework in line with other Greek rituals of male maturation, which were very often Dionysian in nature. ${ }^{63}$ This has often been claimed as indicating both the Dionysian register of the Oschophoria, even within the Classical era, as well as its being an entirely initiatory rite. ${ }^{64}$ While I do not mean to overtly argue against this position, I have already highlighted the diminished role of Dionysus in the ritual's aetiology and execution whilst also being aligned with Plitz, who views the maturation of youths as just one aspect of the Oschophoria.$^{65}$ Particular modes of ritual dress can act as the material media by which new identities are ascribed and communicated, and in the instance of the Oschophoria the donning of female garb distinctly indicates its Thesean framework as allowing for the formulation of the youths' wider socialization as maturing male citizens. ${ }^{66}$ This was framed by the re-collective mimesis embodied in the dress and vine branches of the oschophoroi; where the semantic-cultural mem-

59. FGrHist 327, 6 = Plut., Thes. 23, 2-3.

60. FGrHist 328, 183. Cf. Harding, 2008, p. 62.

61. Od. V 333-462. Cf. Bolich, 2007, pp. 29-41.

62. Achilleid. I 330-333.

63. Leitao, 1995, pp. 131-137; Miller, 1999, p. 153; Jameson, 2014, pp. 62-63; Guardia, 2017, pp. 99108.

64. Deubner, 1932, p. 143; Simon, 1983, p. 90; Walker, 1995, p. 100.

65. Pitz, 2011, p. 151.

66. Leitao, 1999, pp. 247-248; Lee, 2015, p. 204. 
ory of Theseus' foundation of the festival would have intersected with the episodic memory of re-enacting it. This certainly represents "religion in the making", where the annual recollection would be appropriated by differing actors. ${ }^{67}$

Another instance of direct embodied mimesis, this time as enacted by general participants, also directly commemorated points from within the Oschophoria's claimed Thesean aetiology. Upon arriving at the shrine of Athena Skiras at the port of Phaleron, and during the pouring of libations, Plutarch describes that those pres-

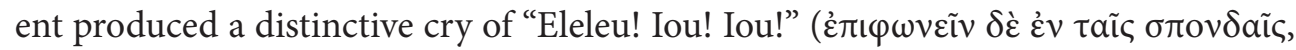

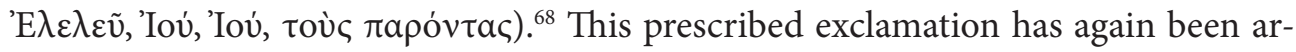
gued as indicating the Oschophoria's originally overt Dionysian character, with the apparent shift from joyous to mourning registers a recognizable feature of vegetation/ fertility rites. ${ }^{69}$ However Plutarch describes these distinct calls as deliberately re-enacting the cries of joy at Theseus' return, and sorrow at the death of King Aegeus who had leapt form the Akropolis thinking his son dead. The suicide of Aegeus as presented by Plutarch is in line with Apollodorus, ${ }^{70}$ while also illustrating the possible appropriation of what was previously a recognized Dionysian aspect into the Thesean framework of the Oschophoria. Building his description on oral tradition ( $\lambda \dot{\varepsilon} \gamma o v \sigma \iota v$, "they say") ${ }^{71}$ if not a direct citation of any, at least surviving, works of the Atthidographers, Plutarch provides an illustration of a re-performance of cultural memory. Commemorative re-performance of specific events are essential in generating the collective memory of a given cultural group's notion of a shared past, which are in turn essential to wider identity structures. ${ }^{72}$ The proscribed repetition of this distinct cry, perceived as originating in the Thesean age, indicates the form of ritualized re-performance that provides temporal depth and perceived connection with the past. ${ }^{73}$ This act would have indicated the competence and membership of the individual within the remembering group, where the direct referencing of a specific moment of the Athenian collective past was achieved via mimesis and within the landscape (the port of Phaleron) of its inception. Moreover, as with the oschophoroi, those that performed the cry may be said to adopt characters from this Thesean episode; the Athenians that welcomed him home. Again the suspension of the self,

67. Rüpke, 2018a, pp. 108-115.

68. Thes. $22,3$.

69. Simon, 1983, p. 91; Calame, 1996, p. 335; Parker, 2005, p. 215.

70. Epit. I 10.

71. Thes. 23, 3.

72. Assmann, 2012, pp. 38-39.

73. Connerton, 1989, p. 59. 
albeit briefly, would have allowed for the reinforcement of notions of a shared, and sacralised, history. ${ }^{74}$

A similar process of adopting figures drawn from the Thesean origins of the Oschophoria are again evident in designated female deipnophoroi ( $\delta \varepsilon ı \pi v o \varphi$ ó "meal-bearers"), ${ }^{75}$ elected by, and from, the genos Salaminoi. They carried the foodstuffs within the procession to Phaleron and are described as sharing in the sacrifice at the shrine of Athena Skiras by Plutarch. ${ }^{76}$ This sacrifice likely included one directly for Theseus, who in the $4^{\text {th }}$ cent. BCE received a pig from the genos. ${ }^{77}$

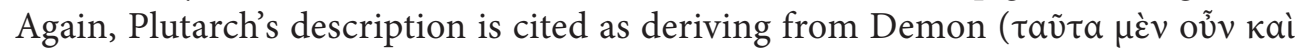

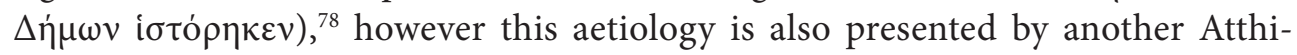
dographer, Philochorus. ${ }^{79}$ The deipnophoroi are thus concretely attested throughout the $5^{\text {th }}-4^{\text {th }}$ cent. BCE with associated Thesean origins. The women themselves were likely chosen from the well-born, thus perfunctorily displaying their status, while adopting the role of "meal-bearers" suggests a form of public recollection that enables being socially situated via religious competence and narration..$^{80}$ Moreover, the deipnophoroi would have acted to communicate the collective past to the participating group by specifically evoking the mothers of the youths and maidens that

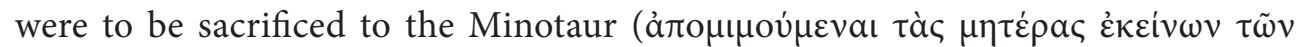

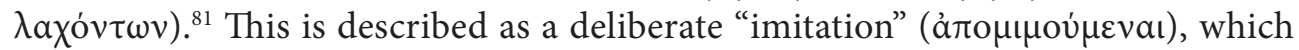
not only indicates the deipnophoroi as specific mnemonic roles, but also forms of embodied memory that would have reinforced the sexed and civic identity of the performers. Again we may discern a ritualized elision of the self that enables the formation of socially situated identities. ${ }^{82}$ Certainly by adopting the role of prototypical mothers, the deipnophoroi would have demonstrated a display of the idealized gendered behavior for Athenian women. ${ }^{83}$

Such performative action can be understood here as endowing a religious agency, where the deipnophoroi performed the communication of collective memory to other participants in their adoption of distinct characters. This was emphasized in

\footnotetext{
74. Rüpke, 2018b, p. 25.

75. Thes. $23,3$.

76. Ferguson, 1938, p. 6.

77. Ferguson, 1938, p. 8.

78. FGrHist 327, 6 = Thes. 23,3 .

79. FGrHist 328, 183. Cf. Harding, 2008, p. 62.

80. Parke, 1986, pp. 80-81; Albrecht et al., 2018, p. 570.

81. Thes. 23, 3 .

82. Waldner, 2000, pp. 103-112.

83. Pomeroy, 1975, pp. 65-68.
} 
the "mothers" telling stories at "the festival", most likely after the sacrifice at Phaleron and the initiation of feasting, which was again conceived as a repetition of the The-

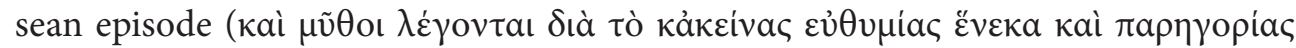

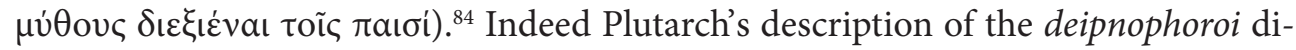

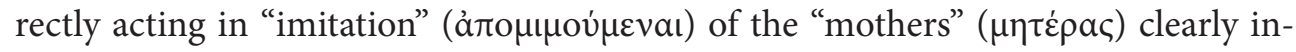
dicates a generation of the collective memory of Theseus within the Oschophoria. In performing as the "mothers", those chosen women would have engaged in a recollection that provided an avenue by which their civic identity as Athenian women was both embodied and displayed ${ }^{85}$ Naturally the spatial arena of Phaleron would have supported this; intersecting re-performance with the landscape of its initiation.

The Oschophoria would have generated the collective memory of the Cretan adventure via various points of direct mimesis, adoption of Thesean roles, and spatial evocation. In the instance of the oschophoroi and deipnophoroi, we are provided an insight into how such mnemonic practice could cultivate socialized and religious identities ${ }^{86}$ By replicating the Thesean origins of the festival itself, for at least these two groups the Oschophoria provided a form of embodied recollection that would have enabled the formative expression of their aged and sexed identities within a wider civic/religious context. While not conforming precisely to Whitehouse's "imagistic" mode, if we consider the experience of the Oschophoria from the perspective of the oschophoroi and deipnophoroi, we can see how in constructively communicating the collective memory of Theseus these participants were afforded the forms of episodic memory required for group fusion. ${ }^{87}$ Indeed while the Oschophoria certainly aligns with general aspects of the "doctrinal" mode, being centrally supervised and routinized in action, as an annual festival it is not high-frequency. However in both the distinct performances of Thesean characters and replication of the festival's origin, such as through the procession and cry, we can certainly see how the Oschophoria would have produced and relied on semantic memory. In recalling this episode from the collective past the wider civic and cultural identity of the festivals participants would have been reinforced. ${ }^{88}$ As Larson has underlined, uniformly assigning any Greek ritual to either imagistic or doctrinal modes is unhelpful, and indeed tends to lean towards the "natural" cognitively optimal/intuitive position. ${ }^{89}$ However we

84. Thes. 23, 3.

85. Assmann, 2010, p. 100.

86. Rüpke, 2018b, p. 26.

87. Manier and Hirst, 2010, pp. 255-257.

88. Whitehouse and Lanman, 2014, p. 679.

89. Larson, 2016, pp. 193-195. 
are granted a better understanding of the formative aspects of the Oschophoria by considering the differing forms of memory generated through the experience of doctrinal and imagistic aspects.

\section{The Pyanopsia: Theseus' Return from Crete and Rites of Maturation}

The day immediately following that of the Oschophoria, the $7^{\text {th }}$ of Pyanopsion, was held the Pyanopsia, and again recalled Theseus leaving Attica and returning from Crete. While firmly Apolline in nature, not least due to the date of the $7^{\text {th }}$ which was sacred to the god in the Athenian religious calendar, this festival claims an overt Thesean aetiology in its description by Plutarch. ${ }^{90}$ This has been argued as being a product of both Salaminian religious interests at Phaleron from the $6^{\text {th }}$ cent. BCE, and indeed the general popularity of Theseus throughout the $5^{\text {th }}$ cent. BCE. ${ }^{11}$ Nevertheless, how far Theseus was simply "grafted on" or found an appropriative emphasis within the Pyanopsia from the $6^{\text {th }}$ cent., is difficult to establish. ${ }^{92}$ In any regard, the Apolline framework is itself given a Thesean origin in Plutarch; after burying Aegeus, Theseus "gave thanks to Apollo on the seventh day of the month" having returned safely

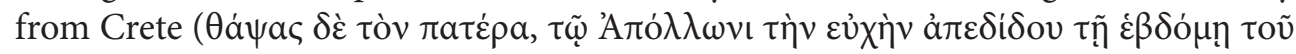

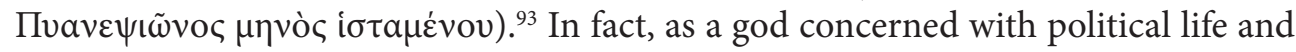
the maturation of youths into adult citizens, Theseus, as the quintessential ephebos and citizen, is repeatedly tied to Apollo Delphinios in Athenian tradition. ${ }^{94}$ Importantly in relation to our focus on collective memory, Plutarch notes another aetiology (on which more below) in his description of the ritual, concluding however that the

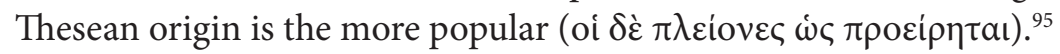

The first aspect of the festival described as stemming directly from Theseus was that of a communal feast as based around a distinct meal of boiled beans, which in fact supplies its aition. ${ }^{96}$ The "custom" of this meal is attributed to Theseus, blending the last of the provisions of the returning youths into "one pot" before arriving at Phaleron:

90. Mikalson, 1975, pp. 69-70; Parker, 2005, p. 480.

91. Parker, 1997, p. 315.

92. Larson, 2016, p. 215.

93. Thes. $22,4$.

94. Graf, 2009, pp. 209-211.

95. Thes. 22, 5.

96. Parke, 1986, p. 75. 


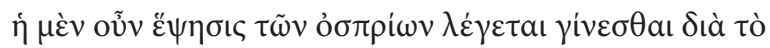

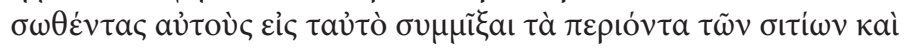

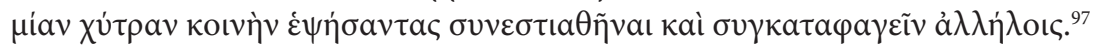

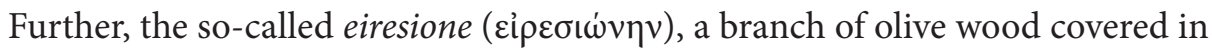
wool and fruits and carried by epheboi during the festival, mimicked the one such

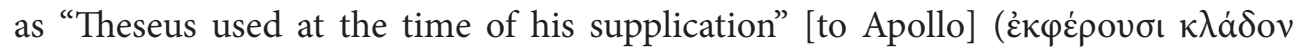

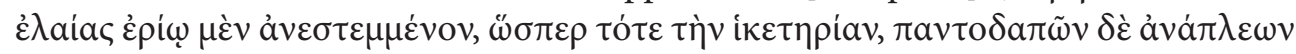
$\kappa \alpha \tau \alpha \rho \gamma \mu \alpha \dot{\tau} \omega \nu) .{ }^{98}$ The carrying of these branches was also accompanied by a song:

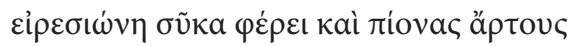

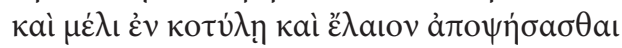

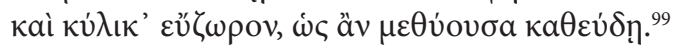

"Eiresione for us brings figs and bread of the richest, brings us honey in pots and oil to rub off from the body, Strong wine too in a beaker, that one may go to bed mellow"

These aspects of the ritual again belie their origin as a vintage festival of an Apolline order, where the fruits of the harvest accompany a meal of unremarkable ingredients to signal the transition into a period of abundance. ${ }^{100}$

Thus Apollo is the recognized focus of the Pyanopsia, but his worship is conducted via a specific commemoration of Theseus' original supplication to the god before sailing to Crete, and his victorious return. As with the Oschophoria we again have an asynchronous Thesean narrative within a ritual whole, yet the manner in which these two points related to each other operated sequentially; eiresione boughs/ supplication, moving towards the feasting/return of the hero. The boughs, as with those held by the oschophori, would have provided general attendants with a material reminder of Theseus' Cretan journey, and while it is uncertain as to whom consumed the proscribed meal of beans, this would have allowed for an embodied engagement with this collective memory.

In relation to those epheboi who carried the eiresione, the Pyanopsia is again illustrated as an arena in which differing forms of collective memory could inform their identity as maturing citizens. Parker suggests that we envisage the Pyanopsia

97. Thes. $22,4$.

98. Thes. $22,5$.

99. Thes. 22, 5.

100. Parke, 1986, p. 76. 
as a diffuse festival, with some depositing their branches in the Temple of Apollo Delphinios in Athens while others carried out similar acts across Attica. ${ }^{101}$ This is certainly suggested in a $4^{\text {th }}$ cent. BCE sacrificial calendar from Elusis, which while fragmentary notes the provision of a pannychis "all night revel" by a "priestesses from Eleusis" on the $7^{\text {th }}$ of Pyanopsion. ${ }^{102}$ Indeed the alternative aetiology of the festival noted by Plutarch also suggests the centrality of epheboi within the festival: "some

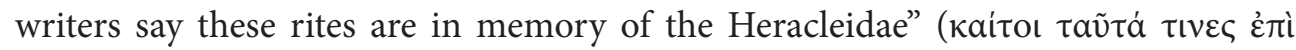

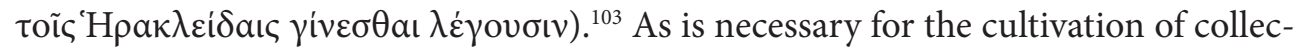
tive cultural memory, the Pyanopsia (at least for those epheboi who deposited their branches in the Temple of Apollo Delphinios) spatially anchored the past into the landscape. ${ }^{104}$ The mnemotopography associated with this temple also recalled the arrival of Theseus to Athens from Troizen, including the quasi-museological display of the place he spilled Medea's cup of poison. ${ }^{105}$ The temple thus displayed physical traces of the arrival of the proto-typical ephebos into the city of Athens and her citizenry. ${ }^{106}$ In context of the Pyanopsia, this space would only reinforce the image of Theseus the Athenian ephebos and citizen par excellence. ${ }^{107}$ This intersection between commemorative mimesis and mnemotopography would naturally communicate the cultural memory at the core of the festival to general participants, while inscribing it in the epheboi via embodied experience.

Again while not containing any dysphoric elements, the Pyanopsia can be understood as enabling forms of episodic memory that would cause a fusion amongst participating epheboi. Not only do we again see the elision of the self and replication of Theseus' actions, but the likely annual exclusivity of the roles would make it a non -repeated religious experience. ${ }^{108}$ Moreover if the "all night revel" was common place, this suggests the form of arena in which the depletion of sensory accuracy enables the formation of cohesive episodic memory. ${ }^{109}$ As such, the Pyanopsia's commemoration of Theseus' Cretan adventure afforded the young men of Attica with the means by which to learn/display semantic memory essential to their civic and cultural identity,

101. Parker, 2005, p. 480.

102. $I G \mathrm{II}^{2} 1363$, 11. 15-20.

103. Thes. 22,5 .

104. Alcock, 2002, pp. 28-30.

105. Paus, I 19, 1. Cf. Greco et al., 2011, pp. 469-474.

106. Hölscher, 2018, p. 118.

107. Shapiro, 1992, p. 44.

108. Whitehouse, 2002, p. 307.

109. Schjødt, 2019, p. 369. 
while its embodied experience could enable the fusion of the maturing epheboi as a conceptual group. In essence, the Pyanopsia illustrates the mnemonic processes which "renders persons, objects and events meaningful by setting them into temporal, spatial and social frames". 110

Similar processes are evident in the foot race that either accompanied this ritual or the Oschophoria. Plutarch does not mention this race, but it does occur in the $2^{\text {nd }}-3^{\text {rd }}$ cent. CE description by Athenaeus who is in turn quoting the $1^{\text {st }}$ cent. BCE grammarian Aristodemus of Nysa. While providing an incorrect date (the $3^{\text {rd }}$ ), this has been identified with the Pyanopsia. ${ }^{111}$ As with Oschophoric procession, the race is described as being run from a shrine of Dionysus in Athens to that of Athena Skiras at Phale-

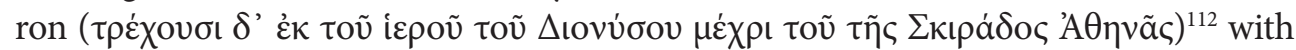

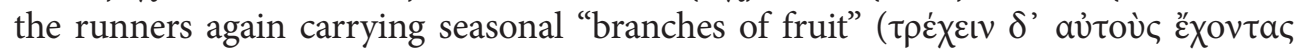

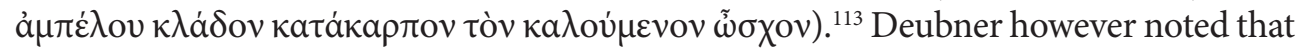
the race course is here likely confused with that of the procession. ${ }^{114}$

The winner was rewarded with a special cup, a pentaplous, in which were

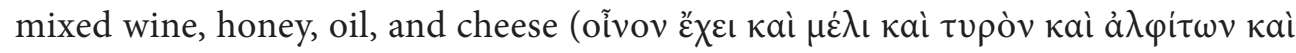

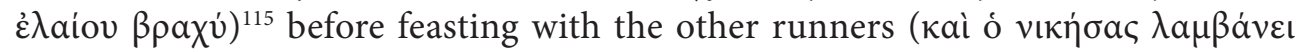

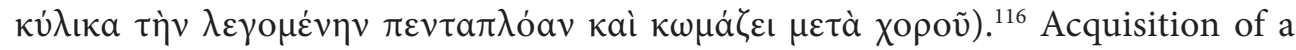
special drink and foodstuffs for the epheboi, certainly aligns with Plutarch's description of the eiresinoe carriers, and indeed the feast mentioned in this context by Aristodemus may also be the prescribed meal of beans. While no specific Thesean aetiology is attached to the foot race in our surviving sources, its course may have included the mnemotopographically charged arena of Phaleron, especially if the meal of beans was eaten at its conclusion. Indeed if this meal was perceived as replicating that originally made by Theseus upon his return, then the port would have been its natural setting. Moreover Robertson's argument that the runners were conceptually equated with the youths that left for Crete, is given credence in Plutarch's description of the Pyanopsia where the epheboi mimic other aspects of Cretan adventure. ${ }^{117}$ As with the ritualized transvestism in the Oschophoria, the

110. Albrecht et al., 2018, p. 583.

111. FGrHist 383, 9. Cf. Robertson, 1992, p. 124.

112. Ath., XI 92.

113. Ath., XI 92. See also Kadletz, 1980, p. 370.

114. Deubner, 1932, p. 145.

115. Ath., XI 92.

116. Ath., XI 92.

117. Robertson, 1992, pp. 124-126. 
display of athletic prowess also indicates an act of public maturation as framed by the collective evocation of the ritual's Thesean origins. ${ }^{118}$

While our evidence relating to the Pyanopsia is not as full as that regarding the Oschophoria, with the foot race still often assigned to the latter, it does illustrate several features essential to generating collective cultural memory. Not only did several points in the festival claim a direct continuation and mimesis of Thesean action, but by doing so in the Temple of Apollo Delphinios, and possibly Phaleron, the spatial evocation inherently required of cultural memory was enabled. ${ }^{119}$ Participation in the Pyanopsia most certainly provided a context by which forms of semantic memory and civic identity could be formulated as based around the memory figure of Theseus. Moreover, the constituent experience of the festival from those epheboi who carried the eiresione, took part in pannychis or foot race, or even in collective singing and feasting, indicates sensory and emotive parameters that would aid in formulating episodic memory. In re-enacting the Thesean past, social competence was both expressed and embodied. By at least the $5^{\text {th }}$ cent. BCE, the prominent evocation of Theseus during the Pyanopsia would have generated the collective memory of the Cretan adventure in association with its mnemotopography and embodied mimesis of its foundation. ${ }^{120}$

\section{The Kybernesia. Hero Worship and the Localization of SAlaminian Memory}

While we have seen how the evocation of Thesean aetiologies aided in producing forms of collective memory conducive to both wider and smaller identity groups, it is also apparent on the level of the genos. Most prominently this was the grouping of the genos Salaminoi, whose religious duties are attested on the $4^{\text {th }}$ cent. stele mentioned above. ${ }^{121}$ As we have seen, this genos was responsible for the organization of the Oschophoria, selecting oschophori and deipnophoroi as well as sacrificing to Theseus and maintaining the cult of Athena Skiras. ${ }^{122}$

However the localization of Salaminoi identity was more prominently reinforced within the commemorative recollection that framed the Kybernesia, celebrated on

118. Golden, 2004, p. 104.

119. Assmann, 2010, pp. 109-111.

120. Jones, 2007, pp. 44-45; Assmann, 2012, p. 34.

121. SEG 21; Ferguson, 1938.

122. Mikalson, 1975, p. 51; Parker, 2005, p. 475.

ARYS, 18, 2020 [213-255] ISSN 1575-166X 
the $8^{\text {th }}$ of Boedromion (September/November). The port of Phaleron was once again

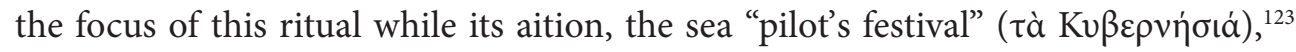
illustrates its nautical tone. Plutarch's brief description of this rite is done so in expressed reference to the Atthidographer Philochorus, stating that Theseus received his look-out man and pilot for the voyage to Crete from the king of the island of Salamis, Skiros:

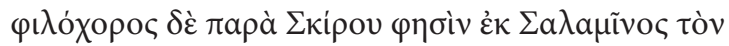

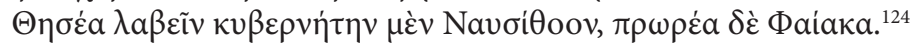

These sailor-men, namely Nausithoös and Phaiax, were directly commemorated within the Kybernesia. As well as employing Philochorus, Plutarch notes how this episode is evidenced in the landscape by their tombs which "Theseus built at

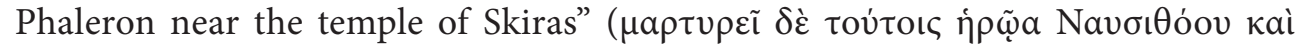

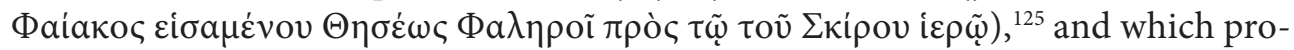
vided the physical focal point of the rite. $4^{\text {th }}$ cent. Salaminian religious duties illustrates required sacrifices to these two heroes as well as Poseidon and another hero, Teukros, on which more briefly. Interestingly Plutarch notes an alternative pilot for the ship as mentioned by Simonides, yet supports his own use of Philochorus by underlining the wider consensus that the Kybernesia commemorated Nausithoös

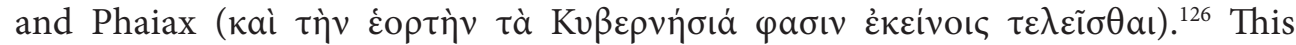
broadly illustrates the means by which culturally available "memory schemata" operate in conjunction with "institutional objects", such as memorials, in the selective generation of collective memory. ${ }^{127}$

In particular, the names of these heroes belie the older, pre-Thesean, form of the Kybernesia. Indeed they are reflective of the sailors par excellence of the heroic age, the Phaiakians, as present in Homer. Within the figure of Nausithoös we may have a familial connection with the divine focus of the rite, Poseidon Hippodromios, if he is indeed that named by Homer as son of the god. ${ }^{128}$ It is perhaps unwise to claim that Theseus had no part in earlier manifestations of the Kybernesia, however the appro-

123. Thes. 17,6 .

124. FGrHist 328, $111=$ Thes. 17,6 .

125. Thes. 17,6 .

126. Thes. 17,6 .

127. Beim, 2010, p. 18.

128. Od. VII 55-57. Cf. Kearns, 1989, p. 39; Larson, 2016, p. 214. See also Jacoby's comments, FGrHist IIIB Suppl. I 347, n. 9. 
priation of Nausithoös and Phaiax as Salaminians and the centrality of the hero in its aetiology, indicates a deliberate "shaping of tradition" by the genos Salaminoi from the $6^{\text {th }}$ cent. BCE. ${ }^{129}$ This can again be assigned to the emphasis on the connections between the island and the genos in the wake of the conflict with Megara, the invasion of Solon and its eventual annexation by at least the end of the century. ${ }^{130}$ Moreover, where Nausithoös may have been celebrated as the son of Poseidon in the Kybernesia, it was surely Theseus that came to be emphasized in this role, especially as the ritual related to the Cretan adventure. In the wake of the Athenian victory at Salamis, and her own emergence as a naval power within the Delian League, Poseidon enjoyed a considerable renaissance in the visual and religious landscapes of the city. ${ }^{131}$ In this context, where Theseus had been previously described as the son of King Aegeus, the hero came to be increasingly depicted as the son of Poseidon. Bacchylides dithyramb 17 provides our most vivid demonstration of this association in which the young Theseus is challenged by Minos on the journey to Crete to prove his divine paternity by descending into the ocean. Indeed the victorious sea journey to Crete, as well as the concept of Theseus as Poseidon's son, naturally proved popular in context of Athenian naval ambition and supremacy. ${ }^{132}$ In any regard, for participants who took part in the Classical era, the understanding of Theseus as a son of Poseidon would have been part of the cognitive schemata which would have informed the collective remembering central to the Kybernesia. ${ }^{133}$

The inclusion of Theseus into a festival structure that honored particular heroes and Poseidon, is certainly in keeping with his escalating popularity from the $6^{\text {th }}$ cent. BCE. As the Kybernesia illustrates, this included Theseus being worshipped alongside his divine father every $8^{\text {th }}$ day on the month. ${ }^{134}$ However the particular nature of the festival also indicates how the likely deliberate inclusion/emphasis of a Thesean aetiology, would have aided in constructing a localizing collective memory for the genos Salaminoi. Nevertheless, the $4^{\text {th }}$ cent. BCE stele detailing the cult responsibilities of the Salaminoi demonstrates that within the Kybernesia, while still responsible for providing sacrificial victims to the god and heroes, the genos did not officiate the entire festival. ${ }^{135}$ Indeed it is likely that due to the

129. Parker, 1997, p. 315.

130. Walker, 1995, p. 51; Valdés Guía, 2002, pp. 175-185.

131. Neils, 2000, pp. 189-191.

132. Shapiro, 1992, p. 37; Mills, 1997, pp. 34-40.

133. Beim, 2010, p. 9.

134. Mikalson, 1975, p. 51.

135. Ferguson, 1938, pp. 8 and 27.

ARYS, 18, 2020 [213-255] ISSN 1575-166X 
principle divine focus being Poseidon, the genos Phoinikes, who held his priesthood at Phaleron, organized the festival. ${ }^{136}$ Yet the mnemotopography and ritual consumed during the Kybernesia reiterated a form of collective remembrance that allows for localized identities and "place bonding" to be cultivated. ${ }^{137}$ This is something indicated by the presence of the hero Teukros in the ritualized honouring of the Kybernesia. ${ }^{138}$ This figure represents a Salaminian hero derived from the island and utterly divorced from Phaeacian and Thesean associations. Again, the promotion of Nausithoös and Phaiax as being Salaminian, and acting within the Thesean framework, most likely rested with the genos. As we have seen, the narrative of Philochorus recognizes the pair as deriving from the Island of Salamis itself, while their hero cult is established inside Attica by Theseus on his return from Crete. ${ }^{139}$

In claiming a Thesean origin, the Kybernesia reflects the ideological and functional incorporation of Salamis into the politico-religious landscape of Attica during the $6^{\text {th }}$ cent. BCE. Debates regarding this "conquest" have been discussed above, but what is important to note here is the manner in which for members of the genos Salaminioi, the Kybernesia afforded the positioning of identity into time and space. ${ }^{140}$ The Salaminian connection to the Cretan adventure represented by Nausithoös and Phaiax, including their memorials being established in Attica proper by Theseus, would have provided a culturally shared collective memory that reinforced their own group identity.

As well as the tombs, the port of Phaleron is illustrated as containing various mnemotopes relating to the Cretan adventure, Theseus, and Salamis. Plutarch de-

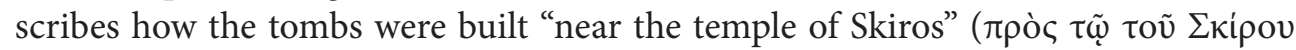
iع $\rho \tilde{\omega}),{ }^{141}$ the king of Salamis who gifted the sea-men. Moreover while the cult of Athena Skiras is indicated as manifesting in Phaleron during the Archaic period, there was certainly a temple to the same goddess on Salamis itself. ${ }^{142}$ Indeed Strabo suggests that this was located on Cape Skiradion, ${ }^{143}$ the place at which Plutarch describes Solon's invasion of the island beginning. ${ }^{144}$ Strabo also states that Skiras was

136. Kearns, 1989, p. 120; Parker, 1997, p. 317.

137. Scannell and Gifford, 2009, pp. 1-5.

138. Ferguson, 1938.

139. FGrHist 328, $111=$ Thes. 17,6 .

140. Assmann, 2012, p. 38.

141. Thes. $17,6$.

142. Hdt., VIII 94. Cf. Papachatzis, 1989, p. 179.

143. Strabo, IX 1, 9.

144. Plut., Sol. 9. 
itself the older title of the island of Salamis, ${ }^{145}$ suggesting both the installation, and deliberate association with Salamis, of the cult of Athena Skiras at Phaleron began in the $6^{\text {th }}$ cent. BCE. ${ }^{146}$ I shall not dwell on the interpretive difficulties relating to the differing manifestations of Skiros, the execution of the cult of Athena Skiras on Salamis, or indeed possible relation to the festival of the Skira, but rather underline how the apparent relationship between Attica and Salamis was evident in the mnemotopography of Phaleron. ${ }^{147}$ This was also the case for the Cretan adventure and Theseus. The, albeit late, description of the Temple of Athena Skiras by Pausanias in the $2^{\text {nd }}$ cent. CE, notes altars to gods, the eponymous Phaleros and "the children of Theseus" (кaì $\pi \alpha i \delta \omega v \tau \tilde{\omega} v \Theta \eta \sigma \dot{\varepsilon} \omega \varsigma){ }^{148}$ Indeed Phaleros and Akamas, the son of Theseus, were held to have colonized Cyprus. ${ }^{149}$ Androgeos, son of Minos, also had an altar there, which is identified by Pausanias through employing local antiquarian knowledge:

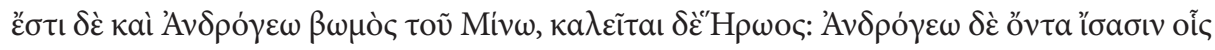

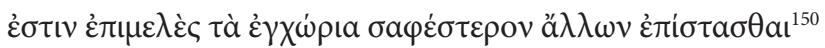

For the identity of the genos Salaminoi, association with the island of Salamis was stressed via association with the sea, while claiming close relation with Theseus emphasized their being situated in Attica. ${ }^{151}$ Within the ritual commemoration of the Kybernesia, the explicit focus on tombs of Nausithoös and Phaiax would have provided the material evidence by which such associations could be prominently communicated within a state festival. Essentially, the appropriative emphasis on the Thesean origins of the tombs and their ritualized veneration would act to spatially and temporally cement their localized identity in relation to both the island and Attica. As physical mnemotopes, these memorials provided the material media essential for the generation of wider cultural collective memory, evoking foundational acts, figures and landscapes, while also referencing the specific group past of the genos Salaminoi. ${ }^{152}$ Indeed while not officiating, the genos would have their group past

145. Strabo, IX 1, 9.

146. Taylor, 1995, pp. 290-291; Parker, 2005, p. 215.

147. Kearns, 1989, p. 198; Håland, 2012, pp. 265-266; Hölscher, 2018, p. 118.

148. Paus., I 1, 4.

149. Valdés Guía, 2005, pp. 62-65.

150. Paus., I 1, 4.

151. Kearns, 1989, p. 40.

152. Jones, 2007, p. 23; Albrecht et al., 2018, p. 572. 
reiterated back to them and general participants, with the island's role in the Cretan adventure being the very cause of the Kybernesia.

The performative and physical arenas of the Kybernesia are illustrated, in their evocation of Thesean origin, as providing the form of ritualized communication essential to cultural memory. ${ }^{153}$ Within a context of ever growing popularity for the hero, the annualized interaction between officiates, the genos Salaminoi, and general participants, would have allowed for the structuring of differing identity forms via this commemorative act. ${ }^{154}$ In essence, the Kybernesia composed of a group recollection that would inform the production of semantic and broader civic-cultural identity, whilst also allowing for the reiteration of a genos specific past and group memory. ${ }^{155}$ The appropriation of Theseus, indicates how the generation of collective memory relies on the contingent interaction between institutional media, such as a festival or memorial, and the socially disseminated understanding of the past. ${ }^{156}$ This included spatially situating the memory of Theseus' return from Crete in the material index provided by the tombs. ${ }^{157}$ How the world is appropriated indicates the means by which individuals and groups avoid alienation and instead stimulate resonance with wider socio-cultural frames, and within the Kybernesia this was performed dualistically. ${ }^{158}$ While the Athenian state had ideologically and literally come to incorporate the island of Salamis into itself, so those members of the genos Salaminoi in Attica are illustrated as appropriating the memory of the pan-Athenian hero as a means by which to orientate themselves. ${ }^{159}$

\section{The Delia. Thesean Mimesis and Ionian Identity}

Within the latter half of the $5^{\text {th }}$ cent. BCE, the strategically important island of Delos also hosted a re-emphasis on the memory figure of Theseus within the Pan-Ionian festival of the Delia. ${ }^{160}$ This annual/quadrennial celebration was cited as being founded by Theseus, with the island a recognized destination on the return voyage back

153. Calame, 2009, p. 25; Assmann, 2012, p. 41.

154. Rüpke, 2018a, p. 14.

155. Manier and Hirst, 2010, p. 258.

156. Beim, 2010, pp. 5-10.

157. Jones, 2007, pp. 12-15.

158. Rosa, 2019, pp. 124-126.

159. Kearns, 1989, p. 120.

160. Connor, 1970, pp. 143-48; Walker, 1995, pp. 13 and 43; Kowalzig, 2007, p. 91; Shapiro, 2019, pp. 215-218. 
from Crete. Athenian participation at the Delia, which took place on the $6^{\text {th }}-7^{\text {th }}$ of Thargelion (May/June), comprised of a theoria of a chorus of korai and epheboi, a ritual ambassador and athletes. While recognized as Pan-Ionian, in the context of the island's "purification" and restoration of the Delia under Athens in 426 BCE, the overt evocation of the memory of Theseus central to this festival is illustrated as emphasizing an Atheno-centric identity. ${ }^{161}$

Indeed this was not the first Athenian purification of the island, as Peisistratus had removed all burials visible from the sanctuary of Delian Apollo to which he likely added the monumental porinos naos, during the 540s BCE. ${ }^{162}$ This has been recognized as a move from tyrannic Athens to formulate an Ionian identity with the city at its conceptual core; something which found a functional reality when the treasury of the Delian League was moved to Athens in 454 BCE. ${ }^{163}$ The sanctuary came under increasing Athenian control through the rest of the century including the establishment of an Athenian-only board of amphictyons, and the purification of 427/426 BCE prohibiting burial, dying and giving birth on the island. ${ }^{164}$ It is in this context that we can view the purposeful emphasis on Thesean origins within a renewed Delia; signalling Athenian control of the island whilst making manifest an Atheno-centric Ionian identity. ${ }^{165}$ This reformed festival naturally provided a more attractive outlet for Athenian self-expression during the Peloponnesian War, than did the great Pan-Hellenic Games. ${ }^{166}$

Thucydides describes how at the time of Athenian re-institution the Delia had in fact fallen from renown, with a larger quadrennial version now also established:

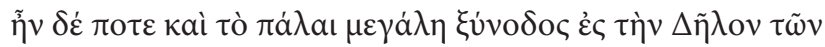

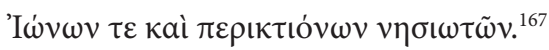

He also directly quotes the Homeric Hymn to Apollo in order to illustrate the older version of the festival:

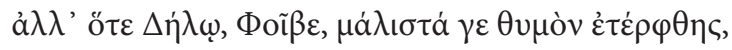

161. Parker, 2005, p. 81.

162. Hdt., I 62, 2; Thuc., III 104, 1-2.

163. Constantakopoulou, 2007, pp. 65-67.

164. Thuc., I 8, 1; III 104; Diod., XII 58, 6.

165. Schachter, 1999, pp. 172-174; Constantakopoulou, 2007, p. 73.

166. Parker, 1997, p. 150.

167. Thuc., III 104. 


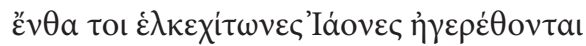

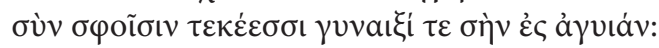

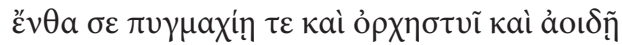

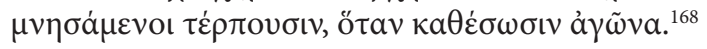

"Here the Ionians gather (...) walking the path of your precinct...delight your heart with boxing, dancing and singing. Every time they hold these games it is you they remember."

Amongst the new additions, Thucydides also notes how the Athenians included

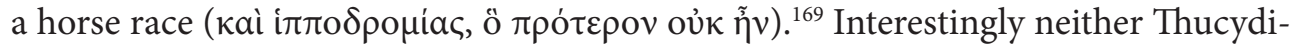
des, nor his earlier source $\left(7^{\text {th }}-6^{\text {th }} \text { cent. BCE }\right)^{170}$ mention the Thesean aetiology for the Delia, and we may suggest this element of the festival as finding especial emphasis in the "new" Athenian manifestation. ${ }^{171}$ Arguments positing a Pan-Ionian origin for Theseus, especially by Herter, ${ }^{172}$ have been convincingly negated, and we should view his evocation during this reformed Delia in relation to his wider representation of Athenian superiority. ${ }^{173}$ This is not to suggest that the recollection of Theseus in any way supressed the cultivation of Ionian identity, but rather aided in doing so via the prism of an Athen-centric memory figure. Where narratives of autochthonic origin had framed conceptions of the Athenian collective past from the late $6^{\text {th }}$ cent., notions of Ionian identity are discernible after the Greco-Persian War and establishment of the Delian League. ${ }^{174}$ Again, the ritualized commemoration of Thesean foundational acts that framed the Delia are thus indicated as operating in a context of a wider aesthetic celebration of Ionian identity, whilst also emphasizing Athenian superiority. ${ }^{175}$ This is certainly the picture presented by Plutarch who describes Nicias leading

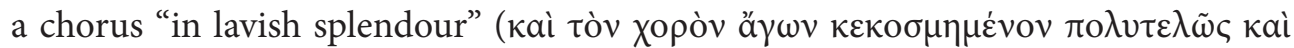

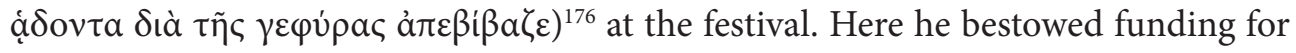
sacred banquets for the Delians, while dedicating a bronze palm-tree which was itself

168. Homeric Hymn of Apollo 145-148.

169. Thuc., III 104.

170. Burkert, 1979, pp. 53-60.

171. Chankowski, 2008, pp. 50-74.

172. Herter, 1936, p. 225; 1939, p. 245.

173. Walker, 1995, pp. 12-13.

174. Connor, 1993, pp. 201-206; Hall, 1997, pp. 51-56.

175. Parker, 1997, pp. 150-151.

176. Nic. 3, 5. 


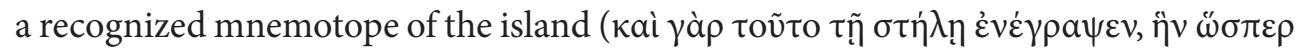

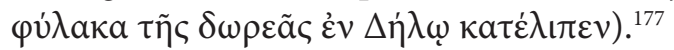

Let us now examine the constituent aspects of the festival illustrated as providing the means by which collective memory is constructed, and how the experience of recalling Theseus would inform differing identities.

Plutarch describes the aetiology of the Delia as originating when Theseus, returning from Crete, put in at Delos and sacrificed to Apollo while also dedicating a statue of Aphrodite Ariadne had given him "in his temple":

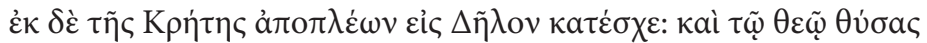

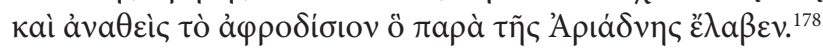

Key elements of the festival, choral singing, athletic contests, the prize of the palm leaf, and distinctive geranos "Crane" were also founded by Theseus:

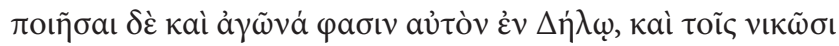
тó

This episode was certainly prevalent during the $5^{\text {th }}$ cent. BCE at least, as evidenced by Pherekydes, who notes that the theoria sent by Athens was also initiated by Theseus in honor of Apollo and Artemis. ${ }^{180}$ Indeed it is suggested that the members of the chorus sent to the Delia were conceived as a re-collective mimesis of the youths and maidens from the Cretan adventure. ${ }^{181}$ Plato relates the theoria sent to the Delia as stemming from a Thesean origin, with it representing the fulfilment of the vows to Apollo for his and the youths safe return:

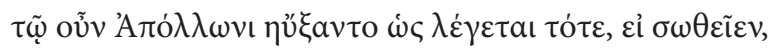

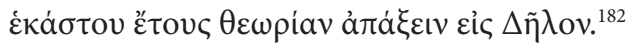

177. Nic. 3, 6. Cf. Marks, 2016, pp. 161-164.

178. Thes. $21,1$.

179. Thes. $21,2$.

180. FGrHist 3, 149; Simon, 1996, p. 12.

181. Larson, 2016, p. 214.

182. Pl., Phaedo 58b. 


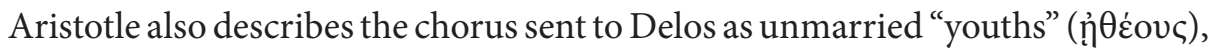
a term specifically used to describe the Thesean epheboi elsewhere, ${ }^{183}$ also mentioning that the chorus members and procession leader were picked together:

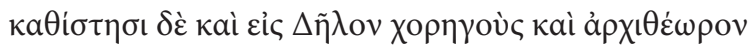

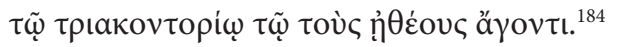

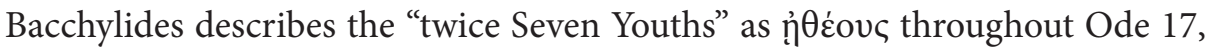
and while designed to be sung by Keans, it suggests the Thesean register of the Delia in the $5^{\text {th }}$ cent. BCE. ${ }^{185}$ Both Plato and Aristotle also illustrate the fact that the theoria delegation journeyed to the festival in a ship understood as being the very one employed during the Cretan expedition:

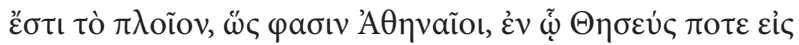

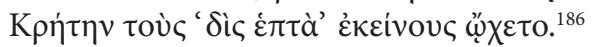

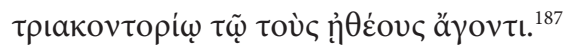

Plutarch also describes this "thirty-oared ship", stating that it was preserved until

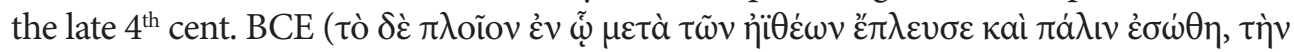

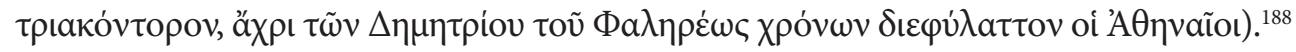

Thus in journeying from Athens to the Delia, those members that made up the theoria performed a continuation of Theseus' proto-typical sacrifice and foundation of athletic contests. The choruses are suggested as being envisioned as directly mimicking the youths and maidens, while the entire crew was literally framed by the material evidence of the Cretan voyage. Commemorative ceremonies naturally aid in the formulation of collective memory via the "depictive representation of past events". ${ }^{189}$ Indeed the theoria dualistically honored the foundation of the Delia by Theseus, while also adopting characters drawn from this episode. While for older members of the theoria, such as ambassadors and chorus leaders, journeying to Delos would have reinforced the semantic memory of this episode in the Athenian past,

183. Parker, 2005, p. 81.

184. A., Ath.Pol. 56, 3.

185. Mills, 1997, p. 39.

186. Pl., Phaedo 58a.

187. A., Ath.Pol. 56, 3.

188. Thes. 23, 1.

189. Connerton, 1989, p. 72. 
for younger members it would have afforded a potent means by which this collective memory was generated bodily. ${ }^{190}$ The ship itself would have provided an immersive experience of a material testament to Theseus' Cretan adventure, something that would have reinforced the adoption of Thesean characters by the chorus. ${ }^{191}$

The most vital mnemonic act of the Delia rested in the performance of the socalled "Crane" dance that Theseus and the twice seven youths initiated. While Plutarch does not expressly link this dance to the Delia, Callimachus presents this association in the $3^{\text {rd }}$ cent. BCE. For his description of the dance however, Plutarch does employs the testimony of the $4^{\text {th }}-3^{\text {rd }}$ cent. BCE philosopher Dicaearchus of Messana:

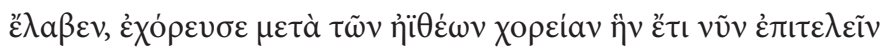

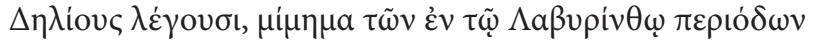

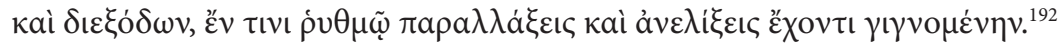

"he danced with his youths a dance which they say is still performed by the Delians, being an imitation of the circling passages in the Labyrinth, and consisting of certain rhythmic involutions and evolutions"

Simon has suggested that as ritualized dance was often perceived as direct mi-

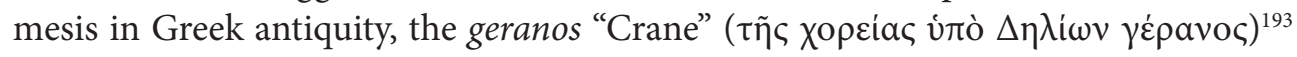
was understood as a direct continuation of the Thesean original. ${ }^{194}$ In his Hymn to Delos, Callimachus describes the dance as an effectually embodied commemoration of its Thesean initiation:

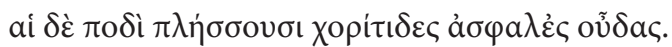

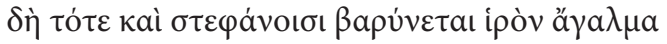

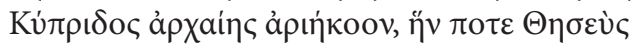

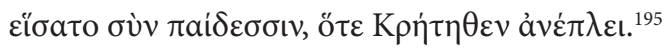

Here the "girls of the choir beat with their feet the secure ground" dancing around the "holy image... of archaic Cypris that Theseus set up with the youths". Moreover the dance is again recognized as imitating the winding nature of the Labyrinth;

190. Connerton, 1989, pp. 45 and 72.

191. Jones, 2007, p. 44; Assmann, 2012, p. 39; Hamilakis, 2014, p. 168.

192. Thes. 21, 1-2. Trans. Perrin, 1914.

193. Thes. $21,2$.

194. Simon, 1996, p. 11; Nagy, 2013, p. 227.

195. Hymn to Delos 305-310. 


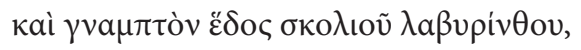

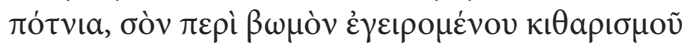

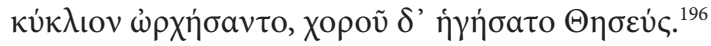

"After fleeing the maze they danced... in a circle... and Theseus led the choir".

The dance is likely to have been performed by Delians even within the context of the Athenian re-organization, however if the choir sent by Athens was promoted as mimicking the youths of the Cretan adventure, then we can imagine that it was they who accompanied it. ${ }^{197}$ Callimachus illustrates that the dance had as its material focal point the statue of Aphrodite, held to have been dedicated by Theseus. Moreover Plutarch describes the dance as encircling the famous "Keraton", an altar to Apollo constructed entirely of bull horns:

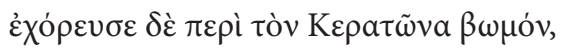

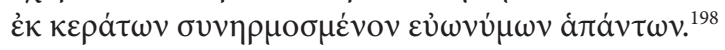

This altar is also mentioned by Callimachus in the Hymn to Apollo, where it is constructed by Artemis (60-64) and was in fact a primary mnemotope in the Delian landscape throughout antiquity, gaining association with Homer as well as Theseus. ${ }^{199}$ As a medium by which the collective memory of Theseus was generated and communicated to participants of the Delia, the "Crane" dance evoked its Thesean origins through embodied mimesis, material cultural and the narration of the Labyrinth episode.$^{200}$ Ceremonial dance acts as a key method by which collective pasts are re-experienced by cultural groups, in effect signalling continuity with that past, something which has been shown as equally formative on the identity of participants and audience alike. ${ }^{201}$ For Athenian members of the chorus and audience, the "Crane" dance would have provided the forms of spatial evocation and perceptions of continuity essential to collective cultural memory. While perhaps not performing the dance the overt focus on Theseus, who had by the late $5^{\text {th }}$ cent. come to represent

196. Hymn to Delos 310-314.

197. Kowalzig, 2007, pp. 56-59.

198. Thes. 21, 2.

199. Marks, 2016, pp. 164-167.

200. Connerton, 1989, p. 44; Halbwachs, 1992, p. 84.

201. Buckland, 2001, pp. 1-16. 
Athens itself, would have underlined an Athens-centric cultural memory as a core element to a Pan-Ionian festival. ${ }^{202}$ Indeed for the other attendees, this recollection of Theseus would have operated in the discernible Thesean flavor of the reorganized Delia that stressed the centrality and superiority of Athens in relation to her allies. ${ }^{203}$

For those that performed the dance and accompanied it with choral singing, this evocation of Theseus and the twice-seven youths demonstrates forms of embodied experience vital to episodic memory and group fusion. ${ }^{204}$ While not overtly ecstatic, the dance as described by both Plutarch and Callimachus is emphasized in being a winding and shifting performance, conducted in relation to the "beat" as established by the choir's singing and stamping feet. Again, whether this chorus was made up of those dancing or others in attendance, is difficult to establish. However, this form of collective singing would have aided in stimulating both relational identities amongst the singers, and collective identities between chorus/dancers and audience. ${ }^{205}$ While energetic dancing and group singing was a common feature within Greek ritual, its ability to create episodic memory was here supported by its likely being performed at night. Inscriptions detailing accessories for the chorus from the $3^{\text {rd }}$ cent. BCE, make repeated reference to torches, wicks, lamps and olive oil required for burning them:

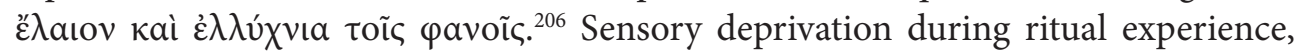
such as darkness, has been shown to allow its episodic recollection to be framed by collective narratives shared after the event. ${ }^{207}$ The notion that the dance was both intricate and completed in the dark is also supported by the mention of ropes ( $\dot{\rho} v \mu o i)$ which may have guided the dancers/chorus. ${ }^{208}$

As with rites discussed above, while not adhering to the dysphoric framework posited by Whitehouse, the carnivalesque experience of dancing and singing at night would have afforded the "fusion" of participants. ${ }^{209}$ The re-enactment of the Thesean "Crane" dance did so within the mnemotopographic, and materially evidenced, landscape of the original. By evoking a distinct figure, episode and space it undoubtedly illustrates its acting as a medium for the generation of collective cultural memory. ${ }^{210}$

202. Chankowski, 2008, pp. 109-118.

203. Parker, 1997, pp. 150-151.

204. Volgsten and Pripp, 2016, pp. 144-164.

205. Rutherford, 2004, pp. 82-90; Pearce, 2017, pp. 196-198.

206. ID 316, 11. 75-80.

207. Schjødt et al., 2013, p. 45; Schjødt, 2019, pp. 367-368.

208. Arnold, 1933, p. 455.

209. Wertsch and Roediger, 2008, p. 323; Downey, 2014, p. 684; Larson, 2016, p. 192.

210. Halbwachs, 1992, p. 200; Assmann, 2012, pp. 38-43.

ARYS, 18, 2020 [213-255] ISSN 1575-166X 
The embodied experience of re-performing this "memory" is also suggested as enabling forms of episodic memory required of group fusion. Adoption of Thesean characters by the dancers/chorus, the apparently complex and winding nature of the dance, group singing and its taking place in near darkness, all indicate embodied, mnemonic, experiences. If the dance was performed by a choir of Delians, then this experience may have supported notions of Athens-centrism. However it may have also reinforced the localized identification and smaller group cohesion of the performers who, while enacting an episode emphasized as Athenian, did so through their own display of religious competence. ${ }^{211}$ Naturally if the Athenian choir took part, the experience would have allowed for a more engrossing adoption of the twiceseven youths with whom they were clearly identified in the context of the Delia.

While the dance firmly demonstrates elements of an "imagistic" ritual experience, the Delia was a calendrically regular, and especially in the context of the Athenian renewal, centrally organized festival. While again not aligning completely with the "doctrinal" religious mode, we gain a better understanding of the Delia's ability to generate, or at least express, an Athens-centric identity by considering overlapping elements. As noted above, Bacchylides suggests that Theseus was indeed a prevalent aspect of the Delia even before its re-organization, and semantic memory would naturally formulate in a ritual context which vividly underlined its foundation by the hero. Yet in the context of overt Athenian control, we may discern the form of directorial authority by which fixed interpretations are communicated to the group. ${ }^{212}$ While still celebrated as a Pan-Ionian festival, the generation of semantic memories regarding Theseus at the Delia during this period would have thus been framed by a retrojection of Athenian influence and supremacy into the island's foundational past. How much this enabled an identification with Athens from other participants, including the Delians who were themselves expelled from the island for a year in $422 \mathrm{BCE},{ }^{213}$ is elusive. Indeed within the $4^{\text {th }}$ cent. BCE, the recollection of Theseus within the Delia did so in a context of expressed resistance to Athenian control of the sanctuary. ${ }^{214}$ For those Athenians established on the island and the visiting theoria however, the commemoration of Theseus would have undoubtedly functioned to reinforce wider civic/cultural identifications. ${ }^{215}$ The festival's celebrated Thesean foundation - from its dancing, athletic and choral contests, the statue of Aphrodite and

211. Kowalzig, 2007, p. 82; Albrecht et al., 2018, pp. 576-577.

212. Assmann, 2012, p. 41; Whitehouse and Lanman, 2014, p. 680.

213. Thuc., V 1.

214. Constantakopoulou, 2016, pp.125-138.

215. Manier and Hirst, 2010, p. 258.

ARYS, 18, 2020 [213-255] ISSN 1575-166x 
the Athenian delegation enacting a fulfilment of the hero's oath to Apollo - suggests the display of a cultural memory that would have aided in orientating the relationship between the city-state and her Ionian allies within the Delian League.

The recollection of Theseus in the Delia of the latter $5^{\text {th }}$ cent. BCE, is demonstrated as providing a legitimization of the wider religio-political authority of Athens in relation to her Ionian allies. For differing participants, the memory of the hero would have been contingent on exterior socio-political developments in Athens, the Delian League and the island of Delos itself. Episodic memories forged during the "Crane" dance likely formulated a cohesive bonding between those that performed it, while the over-arching emphasis on Theseus iterated the semantic/cultural memory conducive to group identifications. Essentially the festival provided an arena in which differing social relationships could be cultivated and re-enforced through collective memory of Theseus. ${ }^{216}$

In Athens the absence of the theoria initiated a strict maintenance of city-wide purity including the cessation of executions, most famously that of Socrates in 399 BCE. ${ }^{217}$ This restriction indicates the liminal quality of "ritual time" as standing apart from the everyday; where the abstract temporality of the Thesean past framed the experience of time in the day-to-day workings of the city. ${ }^{218}$ As the delegation would have engaged with a visceral recollection of the Thesean voyage back from Crete, so the city of Athens itself re-awaited the return of "Theseus" to Phaleron in the form of his ship and the representational youths who had honored the oath sworn by the hero to Apollo.

\section{Conclusion: The Procession to the Delphinion and The Thesean Ritual LANDSCAPE}

The claimed and emphasized Thesean aetiologies within the rituals discussed above, are indicated as providing the required material media, mnemotopic evocation and embodied experiences by which the collective cultural memory is generated. ${ }^{219}$ Rather than representing a petrified canon, the Cretan adventure manifested contextually within these festivals in conjunction with wider socio-cultural developments and requirements. Indeed we have seen how by engaging with this collective memory,

216. Albrecht et al., 2018, p. 583.

217. Xen., Mem. IV 8, 2.

218. Bradley, 1998, p. 85.

219. Assmann, 2012, pp. 38-41. 
differing forms of group identity were provided arenas in which to be cultivated, expressed and imposed.

To conclude this examination the little recorded rite dated to the $6^{\text {th }}$ of Mounichion (April/May) will be considered next to these phenomena. This ritual was formed of a procession of young women to the Temple of Apollo Delphinios near to the Akropolis, who carried olive branches crowned with wool as with the epheboi during the Pyanopsia. ${ }^{220}$ Plutarch is here again our primary source, and while no Atthidographer is cited, the description of the ritual is consistent with the author's wider historiographic archaiologia. ${ }^{221}$ As noted above, the Temple of Apollo Delphinios was heavily associated with the hero. In first arriving at Athens it is here that Theseus is identified by Aegeus, ${ }^{222}$ while Pausanias describes how being taken for a young woman by the temple's builders, he threw a pair of oxen over its roof in a show

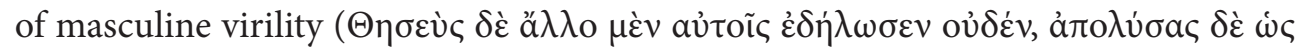

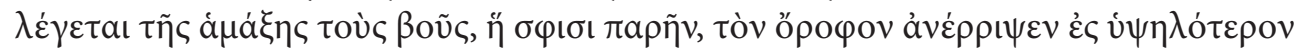

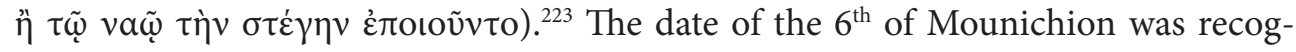
nized as that on which Theseus supplicated Apollo at his temple and then departed for Crete, from which the procession is recognized as emerging. ${ }^{224}$ While little can be gleaned from these details, we are still able to posit on how the procession acted to cultivate collective memory and inform participant's identities.

1) Appropriative emphasis. As with the other rituals above, the procession to the Delphinion is indicated as manifesting situationally, with its Thesean aetiology likely emerging from the $6^{\text {th }}$ cent. BCE. While an evidently Apolline rite, the date of the $6^{\text {th }}$ in fact points to it being originally related to Artemis who was also worshipped in the Delphinion. ${ }^{225}$ Indeed Simon has underlined Artemis as having a prominent position in the earliest versions of the Cretan adventure, and the procession may echo this older relationship. ${ }^{226}$ Nevertheless, the rite as recorded by Plutarch has Apollo as its divine focus, and Theseus' supplication to the god as its cited origin. While admittedly elusive, the apparent elision of Artemis in favor of Apollo suggests an adjustment in line with prevalent conceptions of Theseus' relationship with these gods.

220. Deubner, 1932, p. 201; Calame, 1996, p. 143.

221. Frost, 1984, p. 67.

222. Thes. 12,3 .

223. Paus., I 19, 1.

224. Thes. $18,1$.

225. Mikalson, 1975, p. 140.

226. Simon, 1996, pp. 12-15.

ARYS, 18, 2020 [213-255] ISSN 1575-166X 
2) Maturation and social identity. An older Artemisian form for this procession is perhaps evidenced in the sole participation of young women, for whom Artemis oversaw female maturation rituals in various contexts and guises. ${ }^{227}$ This does not mean that Theseus as a memory figure would have been previously absent, but rather Apollo was not the likely divine focus. In any regard, the Thesean aetiology that framed this rite provided an authorative precursor to what would have been a display of the young women's socio-religious competence. We may again detect elements of embodied mimesis; replicating Theseus' own oath to Apollo while perhaps dualistically evoking the maidens bound for Crete. Such facets of ritualized experience have been illustrated above as allowing for fused bonding, while the replication of a prototypical act would have supported wider identity forms via the commemoration of a shared past for performers and general participants alike. ${ }^{228}$

3) Mnemotopography. The procession as a physical act, would have aided in spatially anchoring the memory of Theseus into the landscape by replicating the movement of his own religiously charged journey to the Temple of Apollo. Collective memory relies on its being positioned into space, and the ritual journey carried out by the young women would have both embedded and evoked the cultural remembrance of this episode from the Athenian heroic past. ${ }^{229}$ Athens and its surrounding landscapes housed various Thesean mnemotopes, however it was through acts such as the procession to the Delphinion that they would be able to formulate collective memory. ${ }^{230}$

4) Materiality. The boughs carried by those in the procession, again as in the Pyanopsia, directly referenced those supposedly dedicated by Theseus in the temple. This may again indicate the appropriation of a directly Thesean origin for a pre-existing aspect of the procession. Religious communication "requires materiality"231 and is vital in the formulation of collective memory. ${ }^{232}$ While obviously not as potent as the tombs at Phaleron or the Thesean ship, the branches would have communicated the memory of the Thesean origins of the procession to it members and audience.

227. Lee, 2015, pp. 200-203.

228. Connerton, 1989, p. 82.

229. Assmann, 2012, p. 42.

230. Alcock, 2002, pp. 28-32; Hölscher, 2018, pp. 118-121.

231. Albrecht et al., 2018, p. 570.

232. Jones, 2007, p. 42. 
5) Religious "modes". While little is gleaned from Plutarch's description of the procession, we may reasonably suggest that the experience of the korai would have enabled episodic memory. While not dysphoric in any sense, themes of maturation and character adoption during the rite indicate potential frameworks for fused identity. Likewise, as an organized state ritual that would have been administered by religious authorities, the procession generally aligns with the "doctrinal" mode. However, as with all the rites discussed above, neither of these definitions fit neatly with this ritual, and we should perhaps approach it as cognitively intuitive overall. ${ }^{233}$ Nevertheless by noting "imagistic" and "doctrinal" elements, we gain a clearer picture of how differing forms of collective memory were likely generated and their potential to inform differing identities.

6) Cultural remembering. Cultural memory deals with the shared origins, heroic figures and important landscapes of groups. It requires communication through mimesis, mnemotopography and various material reminders in the form of ritualized acts. ${ }^{234}$ The procession would have clearly operated as a medium by which the Athenian collective memory of Theseus was generated and expressed; re-performing his original supplication within its established mnemotopography.

By considering the contingent nature and experience of ritual, we are provided with firmer ground in commenting on its formative properties. In this paper I have aimed to consider these issues in relation to the mechanics by which collective memory was generated, not simply expressed. For those rites that claimed Thesean origin, we have seen how the hero was subject to situational emphasis in relation to wider socio-political and religious realities. Collective memory is ever a product of the present, and the manner in which the Cretan adventure was commemorated indicates how the past is selectively emphasized to "serve contemporary goals". 235 Through a direct examination of the media by which the collective memory of Theseus was itself generated, we have seen how these rituals acted to spatially anchor the hero into the landscape through re-enactment, and often in conjunction with either material evidences or reminders. While never attempting to conform these rituals to rigid definitions of "doctrinal" or "imagistic" religious modes, these frameworks have been helpful in considering how episodic and semantic memory was formulated therein. In the

233. Larson, 2016, p. 192.

234. Wertsch and Roediger, 2008, p. 324; Assmann, 2010; pp. 110-111.

235. Pantel, 2013, p. 433.

ARYS, 18, 2020 [213-255] ISSN 1575-166X 
cases of direct mimesis, adoption of Thesean characters and sensory elision we have seen the potential for bonding between participating groups via embodied cognition. Likewise, the routinized commemoration of Theseus through re-performance, material evidencing and mnemotopography allowed for the display of maturing, sexed, genos and civic identity. Indeed, as the central hero and representative of Athens from the $6^{\text {th }}$ cent. $\mathrm{BCE}$, the notion that any collective recollection of Theseus contributed to a wider Athenian group identification is uncontroversial. However, by shifting focus towards the mechanics by which this was produced we have gained a fuller picture of the contingent quality and experience of the collective memory of Theseus. 


\section{Bibliography}

Albrecht, J., Degelmann, C., Gasparini, V., Gordon, R., Petridou, G., Raja, R., Rüpke, J., Sippel, B., Urciuoli, E. and Weiss, L. (2018). Religion in the Making: The Lived Ancient Religion Approach. Religion, 48.4, pp. 568-593.

Alcock, S.E. (2002). Archaeologies of the Greek Past. Landscape, Monuments, and Memories. Cambridge and New York: Cambridge University Press.

Arnold, R. (1933). Local Festivals at Delos. American Journal of Archaeology, 37.3, pp. 452458.

Assmann, J. (2010). Communicative and Cultural Memory. In Erll and Nünning, 2010, pp. 109-118.

Assmann, J. (2012). Cultural Memory and Early Civilization. Writing, Remembrance and Political Imagination. Cambridge and New York: Cambridge University Press.

Beck, H. (ed.) (2013). A Companion to Ancient Greek Government. Chichester: Blackwell Publishing.

Beim, A. (2010). The Cognitive Aspects of Collective Memory. Symbolic Interaction, 30.1, pp. 7-27.

Bernabé Pajares, A. (1992). El mito de Teseo en la poesía arcaica y clásica. In Olmos Romera, 1992, pp. 97-118.

Böhr, E. (2007). Ein Jüngling beim Fest der Oschophoria? In Christof et al., 2007, pp. 69-73.

Bolich, D.G.G. (2007). Transgender History \& Geography. Crossdressing in Context, III: Crossdressing in Context. Raleigh, North Carolina: Psyche.

Bowersock, G.W., and Knox, B. (eds.) (1979). Arktouros: Hellenic Studies Presented to B. M. W. Knox. Berlin: De Gruyter.

Bradley, R. (1998). The Significance of Monuments. On the Shaping of Human Experience in Neolithic and Bronze Age Europe. London and New York: Routledge.

Brenk, F. (2017). Fredrick Brenk on Plutarch, Religious Thinker and Philosopher. Leiden and Boston: Brill.

Brommer, F. (1982). Theseus. Die Taten des griechischen Helden in der antiken Kunst und Literatur. Darmstadt: Wissenschaftliche Buchgesellschaft.

Brown, S. (2013). Religious Ritual and the Loss of Self. Religion, Brain and Behavior, 3.1, pp. 58-60.

Buckland, J. (2001). Dance, Authenticity and Cultural Memory: The Politics of Embodiment. Yearbook for Traditional Music, 33, pp. 1-16.

Buitron-Oliver, D. (ed.) (1991). New Perspectives in Early Greek Art. Washington: National Gallery of Art.

Burkert, W. (1979). Kynaithos, Polycrates and the Homeric Hymn to Apollo. In Bowersock and Knox, 1979, pp. 53-62.

Calame, C. (1996). Thesée et l' imaginaire athenien: Legende et culte en Grece antique. Lausanne: Payot. 
Calame, C. (2009). Poetic and Performative Memory in Ancient Greece. Heroic Reference and Ritual Gestures in Time and Space. Washington, D.C.: Center for Hellenic Studies Harvard University.

Campanile, D., Carla-Uhink, F. and Facella, M. (eds.) (2017). TransAntiquity. Cross-Dressing and Transgender Dynamics in the Ancient World. London and New York: Routledge.

Chankowski, V. (2008). Athènes et Délos à l'époque classique: Recherches sur l'administration du sanctuaire d'Apollon Délien. Athènes: École française d'Athènes.

Christof, E. et al. (eds.) (2007). Potnia theron: Festschrift für Gerda Schwarz zum 65. Geburtstag. Vienna: Phoibos.

Cingano, E. (2017). Epic Fragments on Theseus: Hesiod, Cercops, and the Theseis. In Derda, Hilder and Kwapisz, 2017, pp. 309-332.

Connerton, P. (1989). How Societies Remember. Cambridge and New York: Cambridge University Press.

Connor, W.R. (1970). Theseus in Classical Athens. In Ward et al., 1970, pp. 143-175.

Connor, W.R. (1993). The Ionian Era of Athenian Civic Identity. Proceedings of the American Philosophical Society, 137.2, pp. 194-206.

Cooper, C. (2007). Making Irrational Myth Plausible History. Polybian Intertextuality in Plutarch's Theseus. Phoenix, 61, pp. 212-233.

Constantakopoulou, C. (2007). The Dance of the Islands. Insularity, Networks, the Athenian Empire, and the Aegean World. Oxford: Oxford University Press.

Constantakopoulou, C. (2016). The Shaping of the Past. Local History and Fourth-Century Delian Reactions to Athenian Imperialism. In Powell and Meidani, 2016, pp. 125-146.

Cusumano, N. (2013). Memory and Religion in the Greek World. In Cusumano et al., 2013, pp. 17-19.

Cusumano, N., Gasparini, V., Mastrocinque, A. and Rüpke, J. (eds.). Memory and Religious Experience in the Greco-Roman World. Stuttgart: Franz Steiner.

Derda, T.J., Hilder, J. and Kwapisz, J. (2017). Fragments, Holes, and Wholes. Reconstructing the Ancient World in Theory and Practice. Warsaw: Fundacja im. Rafała Taubenschlaga.

Deubner, L. (1932). Attische Feste. Berlin: Heinrich Keller.

Erll, A. and Nünning, A. (eds.) (2010). A Companion to Cultural Memory Studies. Berlin and New York: De Gruyter.

Ferguson, W.S. (1938). The Salaminioi of Heptaphylai and Sounion: The American Excavations in the Athenian Agora: Thirteenth Report. Hesperia. The Journal of the American School of Classical Studies at Athens, 7.1, pp. 1-74.

Frost, F.J. (1984). Plutarch and Theseus. The Classical Bulletin, 60.4, pp. 65-73.

Gagné, R. et al. (eds.) (2013). Choral Mediations in Greek Tragedy. Cambridge and New York: Cambridge University Press.

Gehrke, H.J., Luraghi, N. and Foxhall, L. (eds.) (2010). Intentional History. Spinning Time in Ancient Greece. Stuttgart: Franz Steiner.

Golden, M. (2004). Sport and Society in Ancient Greece. Cambridge and New York: Cambridge University Press. 
Goušchin, V. (1999). Athenian Synoikism of the Fifth Century B.C., Or Two Stories of Theseus. Greece and Rome, 46.2, pp. 168-187.

Graf, F. (2009). Apollo. London and New York: Routledge.

Greco, E. et al. (2011). Topografia di Atene. Sviluppo urbano e monumenti dalle origini al III secolo a.C., Tomo II: Colline sud-occidentali - Valle dell'Ilisso. Atene and Paestum: Pandemos.

Guardia, F. (2017). Aspects of Transvestism in Greek Myths and Rituals. In Campanile, Carla-Uhink and Facella, 2017, pp. 99-107.

Håland, E.J. (2012). The Ritual Year of Athena. The Agricultural Cycle of the Olive, Girls' Rites of Passage, and Official Ideology. Journal of Religious History, 36.2, pp. 256-284.

Halbwachs, M. (1992). On Collective Memory. Chicago: Chicago University Press.

Hall, J.M. (1997). Ethnic Identity in Greek Antiquity. Cambridge and New York: Cambridge University Press.

Hamilakis, Y. (2014). Archaeology and the Senses. Human Experience, Memory, and Affect. Cambridge and New York: Cambridge University Press.

Harding, P. (2008). The Story of Athens. The Fragments of the Local Chronicles of Attika. London and New York: Routledge.

Haysom, M. and Wallensten, J. (eds.) (2011). Current Approaches to Religion in Ancient Greece. Papers Presented at a Symposium at the Swedish Institute at Athens, 17-19 April 2008. Stockholm: Skrifter utgivna av Svenska Institutet i Athen.

Hedreen, G. (2011). Bild, Mythos, and Ritual: Choral Dance in Theseus's Cretan Adventure on the François Vase. The Journal of the American School of Classical Studies at Athens, 80.3, pp. 491-510.

Herter, H. (1936). Theseus der Jonier. Rheinisches Museum, 85, pp. 177-239.

Herter, H. (1939). Theseus der Athener. Rheinisches Museum, 88, pp. 244-326.

Hewer, C.J. and Roberts, R. (2012). History, Culture and Cognition. Towards a Dynamic Model of Social Memory. Culture and Psychology, 18.2, pp. 167-183.

Hölscher, T. (2018). Visual Power in Ancient Greece and Rome. Between Art and Social Reality. Oakland, California: University of California Press.

Jameson, M.H. (2014). Cults and Rites in Ancient Greece. Essays on Religion and Society. Cambridge and New York: Cambridge University Press.

Jones, A. (2007). Memory and Material Culture. Cambridge and New York: Cambridge University Press.

Kadletz, E. (1980). The Race and Procession of the Oschophoria. Greek, Roman and Byzantine Studies, 21, pp. 363-371.

Kearns, E. (1989). The Heroes of Attica. London: Institute of Classical Studies.

Kowalzig, B. (2007). Singing for the Gods. Performances of Myth and Ritual in Archaic and Classical Greece. Oxford and New York: Oxford University Press.

Kron, U. (1976). Die zehn attischen Phylenheroen. Berlin: Mann.

Lambert, S.D. (1997). The Attic Genos Salaminioi and the Island of Salamis. Zeitschrift für Papyrologie und Epigraphik, 119, pp. 85-106. 
Larmour, D.H.J. (1988). Plutarch's Compositional Methods in the Theseus and Romulus. Transactions of the American Philological Association, 118, pp. 361-375.

Larson, J. (2016). Understanding Greek Religion. London and New York: Routledge.

Leitao, D.D. (1995). The Perils of Leukippos. Initiatory Transvestism and Male Gender Ideology in the Ekdusia at Phaistos. Classical Antiquity, 14.1, pp. 130-163.

Leitao, D.D. (1999). Solon on the Beach: Some Pragmatic Functions of the Limen in Initiatory Myth and Ritual. In Padilla, 1999, pp. 247-277.

Lee, M.M. (2015). Body, Dress, and Identity in Ancient Greece. Cambridge and New York: Cambridge University Press.

Luce, J.M. (1998). Thésée, le synoecisme et l'Agora d'Athènes. Revue Archéologique, 1, pp. 3-31.

Manier, D. and Hirst, W. (2010). A Cognitive Taxonomy of Collective Memories. In Erll and Nünning, 2010, pp. 253-262.

Marincola, J., Llewelyn-Jones, Ll. and Maciver, C. (eds.) (2012). Greek Notions of the Past in the Archaic and Classical Eras. History without Historians. Edinburgh: Edinburgh University Press.

Marks, J. (2016). Odysseus and the Cult of Apollo at Delos. Revista Classica, 29.1, pp. 157-170.

Mikalson, J.D. (1975). The Sacred and Civil Calendar of the Athenian Year. Princeton, New Jersey: Princeton University Press.

Miller, M. (1999). Reexamining Transvestism in Archaic and Classical Athens: The Zewadski Stamnos. American Journal of Archaeology, 103.2, pp. 223-253.

Mills, S. (1997). Theseus, Tragedy, and the Athenian Empire. New York: Oxford University Press.

Murray, P. and Wilson, P. (eds.) (2004). Music and the Muses. The Culture of Mousike in the Classical Athenian City. Oxford and New York: Oxford University Press.

Nagy, G. (2013). The Delian Maidens and Their Relevance to Choral Mimesis in Classical Drama. In Gagné, 2013, pp. 227-256.

Neils, J. (1987). The Youthful Deeds of Theseus. Roma: Giorgio Bretschneider.

Neils, J. (1994). S.v. “Theseus”. LIMC, 7, pp. 922-923.

Neils, J. (1995). Inventing the Other: The Opponents of Theseus. Source: Notes in the History of Art, 15.1, pp. 17-24.

Neils, J. (ed.) (1996). Worshipping Athena: Panathenaia and Parthenon. Madison, Wisconsin: University of Wisconsin Press.

Neils, J. (2000). The Parthenon Frieze. Cambridge and New York: Cambridge University Press.

Ogden, D. (ed.) (2007). A Companion to Greek Religion. Malden, Massachusetts: Blackwell Publishing.

Olmos Romera, R. (1992). Teseo y la Copa de Aison: Imagen de portada del libro Coloquio sobre Teseo y la Copa de Aison. Madrid: CSIC.

Osborne, R. (1994). Archaeology, the Salaminioi, and the Politics of Sacred Space in Archaic Attica. In Osborne and Alcock, 1994, pp. 143-160. 
Osborne, R. and Alcock, S.E. (eds.) (1994). Placing The Gods. Sanctuaries and Sacred Space in Ancient Greece. New York: Oxford University Press.

Padilla, M.W. (1999). Rites of Passage in Ancient Greece: Literature, Religion and Society. Lewisburg, Pennsylvania: Bucknell University Press.

Pantel, P.S. (2013). State Festivals and Celebrations. In Beck, 2013, pp. 432-447.

Papachatzis, N. (1989). The Cult of Erechtheus and Athena on the Acropolis of Athens. Kernos, 2, pp. 175-185.

Parke, H.W. (1986). Festivals of the Athenians. London: Thames and Hudson.

Parker, R. (1997). Athenian Religion. A History. Oxford: Clarendon Press.

Parker, R. (2005). Polytheism and Society at Athens. Oxford: Oxford University Press.

Pearce, E. et al. (2017). Tuning in to Others. Exploring Relational and Collective Bonding in Singing and Non-Singing Groups over Time. Psychology of Music, 45.4, pp. 496-512.

Petersen, A.K et al. (eds.) (2019). Evolution, Cognition, and the History of Religion: A New Synthesis. Festschrift in Honour of Armin W. Geertz. Leiden: Brill.

Pitz, O. (2011). The Performative Aspect of Greek Ritual. The Case of the Athenian Oschophoria. In Haysom and Wallensten, 2011, pp. 151-167.

Pomeroy, S.B. (1975). Goddesses, Whores, Wives and Slaves. New York: Schocken Books Inc.

Powell, A. and Meidani, K. (eds.) (2016). "The Eyesore of Aigina": Anti-Athenian Attitudes across the Greek, Hellenistic, and Roman Worlds. Swansea: The Classical Press of Wales.

Robertson, N. (1992). Festivals and Legends. The Formation of Greek Cities in the Light of Public Ritual. Toronto: University of Toronto Press.

Rosa, H. (2019). Resonance. A Sociology of Our Relationship to the World. Cambridge: Polity Press.

Rüpke, J. (2018a). Pantheon: A New History of Roman Religion. Princeton: Princeton University Press.

Rüpke, J. (2018b). Religious Agency, Sacralisation and Tradition in the Ancient City. Journal of Historical Researches, 29, pp. 22-38.

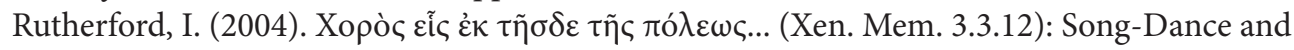
State Pilgrimage at Athens. In Murray and Wilson, 2004, pp. 67-90.

Schachter, A. (1999). The Nyktophylaxia of Delos. Journal of Hellenic Studies, 119, pp. 172174.

Schjødt, U. et al. (2013). The Resource Model and the Principle of Predictive Coin. A Framework for Analysing Proximate Effects of Ritual. Religion, Brain and Behavior, 3.1, pp. 79-86.

Schjødt, U. (2019). Predictive Coding in the Study of Religion: a Believer's Testimony. In Petersen et al., 2019, pp. 364-379.

Scannell, L. and Gifford, R. (2009). Defining Place Attachment. A Tripartite Organizing Framework. Journal of Environmental Psychology, 30, pp. 1-10.

Scullion, S. (2007). Festivals. In Ogden, 2007, pp. 190-203.

Shapiro, H.A. (1991). Theseus: Aspects of the Hero in Archaic Greece. In Buitron-Oliver, 1991, pp. 123-139. 
Shapiro, H.A. (1992). Theseus in Kimonian Athens: The Iconography of Empire. Mediterranean Historical Review, 7.1, pp. 29-49.

Shapiro, H.A. (2012). Attic Heroes and the Construction of the Athenian Past in the Fifth Century. In Marincola, Llewelyn-Jones and Maciver, 2012, pp. 160-182.

Shapiro, H.A. (2019). The Theoris of Theseus. Journal of Western Classics, pp. 25-46.

Simon, E. (1983). Festivals of Attica: An Archaeological Commentary. Madison, Wisconsin: Wisconsin University Press.

Simon, E. (1996). Theseus and Athenian Festivals. In Neils, 1996, pp. 9-26.

Taylor, M.C. (1995). A Fourth-Century Honorary Decree of the Athenian Demos on Salamis. ZPE, 107, pp. 289-295.

Taylor, M.C. (1997). Salamis and the Salaminioi. The History of an Unofficial Athenian Demos. Amsterdam: Gieben.

Tsetskhladze, G.R. (ed.) (2005). Ancient West \& East, 4.1. Leiden and Boston: Brill.

Valdés Guía, M. (2002). Política y religión en Atenas arcaica: La reorganización de la polis en época de Solón. Una revisión de la documentación arqueológica, literaria y religiosa. Oxford: Archaeopress.

Valdés Guía, M. (2005). The Cult of Aglauros (and Aphrodite) in Athens and in Salamis of Cyprus: Reflections on the Origin of the Genos of the Salaminioi. In Tsetskhladze, 2005, pp. 57-76.

Valdés Guía, M. (2009). La recreación del pasado en el imaginario griego: el mito de Teseo y su utilización como fuente histórica. Dialogues d'Histoire Ancienne, 35.1, pp. 11-40.

Van den Hoff, R. (2010). Media for Theseus, or: The Different Images of the Athenian Polis-Hero. In Gehrke, Luraghi and Foxhall, 2010, pp. 161-188.

Volgsten, U. and Pripp, O. (2016). Music, Memory, and Affect Attunement. Connecting Kurdish Diaspora in Stockholm. Culture Unbound: Journal of Current Cultural Research, 8, pp. 144-164.

Waldner, K. (2000). Geburt und Hochzeit des Kriegers - Geschlechterdifferenz und Initiation in Mythos und Ritual der griechischen Polis. Berlin: De Gruyter.

Walker, H. (1995). Theseus and Athens. New York: Oxford University Press.

Ward, A., Connor, W.R., Edwards, R., and Tidworth, S. (eds.) (1970). The Quest for Theseus. London: Pall Mall.

Wertsch, J.V. and Roediger, H.L. (2008). Collective Memory. Conceptual Foundations and Theoretical Approaches. Memory, 16.3, pp. 318-326.

Whitehouse, H. (2002). Modes of Religiosity. Towards a Cognitive Explanation of the Socio-political Dynamics of Religion. Method and Theory in the Study of Religion, 14.3-4, pp. 293-315.

Whitehouse, H. and Lanman, J.A. (2014). The Ties That Bind Us: Ritual, Fusion, and Identification. Current Anthropology, 55.6, pp. 674-695. 